\title{
Localization and Sub-Cellular Shuttling of HTLV-1 Tax with the miRNA Machinery
}

\author{
Rachel Van Duyne ${ }^{1,2}$, Irene Guendel ${ }^{1}$, Zachary Klase ${ }^{3}$, Aarthi Narayanan ${ }^{1}$, William Coley ${ }^{2}$, \\ Elizabeth Jaworski ${ }^{1}$, Jessica Roman ${ }^{1}$, Anastas Popratiloff ${ }^{4}$, Renaud Mahieux ${ }^{5}$, Kylene Kehn-Hall ${ }^{1}$, \\ Fatah Kashanchi ${ }^{1,2 *}$
}

1 Department of Molecular and Microbiology, National Center for Biodefense \& Infectious Diseases, George Mason University, Manassas, Virginia, United States of America, 2 Department of Microbiology, Immunology, \& Tropical Medicine, The George Washington University Medical Center, Washington, D.C., United States of America, 3 Molecular Virology Section, Laboratory of Molecular Microbiology, National Institute of Allergy and Infectious Diseases, National Institutes of Health, Bethesda, Maryland, United States of America, 4 Department of Anatomy and Regenerative Biology, The George Washington University, Washington, D.C., United States of America, 5 Retroviral Oncogenesis Team, INSERM-U758 Virologie Humaine, Lyon, France

\begin{abstract}
The innate ability of the human cell to silence endogenous retroviruses through RNA sequences encoding microRNAs, suggests that the cellular RNAi machinery is a major means by which the host mounts a defense response against present day retroviruses. Indeed, cellular miRNAs target and hybridize to specific sequences of both HTLV-1 and HIV-1 viral transcripts. However, much like the variety of host immune responses to retroviral infection, the virus itself contains mechanisms that assist in the evasion of viral inhibition through control of the cellular RNAi pathway. Retroviruses can hijack both the enzymatic and catalytic components of the RNAi pathway, in some cases to produce novel viral miRNAs that can either assist in active viral infection or promote a latent state. Here, we show that HTLV-1 Tax contributes to the dysregulation of the RNAi pathway by altering the expression of key components of this pathway. A survey of uninfected and HTLV-1 infected cells revealed that Drosha protein is present at lower levels in all HTLV-1 infected cell lines and in infected primary cells, while other components such as DGCR8 were not dramatically altered. We show colocalization of Tax and Drosha in the nucleus in vitro as well as coimmunoprecipitation in the presence of proteasome inhibitors, indicating that Tax interacts with Drosha and may target it to specific areas of the cell, namely, the proteasome. In the presence of Tax we observed a prevention of primary miRNA cleavage by Drosha. Finally, the changes in cellular miRNA expression in HTLV1 infected cells can be mimicked by the add back of Drosha or the addition of antagomiRs against the cellular miRNAs which are downregulated by the virus.
\end{abstract}

Citation: Van Duyne R, Guendel I, Klase Z, Narayanan A, Coley W, et al. (2012) Localization and Sub-Cellular Shuttling of HTLV-1 Tax with the miRNA Machinery. PLoS ONE 7(7): e40662. doi:10.1371/journal.pone.0040662

Editor: Dong-Yan Jin, University of Hong Kong, Hong Kong

Received February 1, 2012; Accepted June 11, 2012; Published July 10, 2012

Copyright: (c) 2012 Van Duyne et al. This is an open-access article distributed under the terms of the Creative Commons Attribution License, which permits unrestricted use, distribution, and reproduction in any medium, provided the original author and source are credited.

Funding: The confocal images and the GWU CMIA are supported by a grant from the NIH, National Center for Research Resources, 1S10RR025565. Further support came from grants from the George Mason university funds to FK and NIH grants AI078859 and Al074410-01. The funders had no role in study design, data collection and analysis, decision to publish, or preparation of the manuscript.

Competing Interests: The authors have declared that no competing interests exist.

*E-mail: fkashanc@gmu.edu

\section{Introduction}

Human T-lymphotropic virus type 1 (HTLV-1) was originally discovered in 1980, identified as the first human retrovirus, and currently infects more than 20 million people worldwide [1-5]. HTLV-1 is the etiologic agent of adult T-cell leukemia/lymphoma (ATLL) and HTLV-1-associated myelopathy/tropical spastic paraparesis (HAM/TSP) in infected individuals. Oncogenesis is due primarily to the viral transactivator protein, Tax, a $40-\mathrm{kDa}$ phosphoprotein that regulates not only viral transcription, but acts to manipulate host cellular functions such as cell cycle progression, apoptosis, chromatin remodeling, and other signal transduction pathways [6-8]. Recently, much interest has developed in elucidating the cross-talk between tumor development and HTLV-1 infection as it relates to the innate host response, in particular the small RNA regulatory network.

Human microRNA (miRNA) sequences derived from the genome have the ability to silence cellular genes and are currently considered a primary host immune defense against cellular invaders such as pathogens and viruses. In a host cell, miRNAs are the product of the RNA interference (RNAi) pathway, a regulatory and innate defense mechanism that is conserved in eukaryotes. This pathway utilizes short non-coding RNA sequences of 18-21 nucleotides to bind to mRNA sequences with complementary homology, subsequently restricting the translation of these transcripts [9]. Following RNA Pol II transcription of a gene, the Pri-miRNA consists of a series of RNA hairpins protruding from an RNA message with a 5'cap and poly-A tail. This Pri-miRNA is cleaved by a microprocessor complex of nuclear proteins, Drosha, an RNase II endonuclease, and DCGR8 (Pasha), an RNA-binding protein, to form a stem and loop RNA-structure called Pre-miRNA. This PremiRNA is shuttled out of the nucleus into the cytoplasm via Exportin5 and is further processed by an additional RNase III enzyme, Dicer, which cleaves the hairpin into a short miRNA duplex. These miRNA then associate with the RNA induced silencing complex (RISG), composed of Ago2 and TRBP 
proteins, which then aids in miRNA-mediated target recognition. This guide effector protein complex assists in either degrading the targeted message or preventing its translation [10]. The dysregulation of this pathway is highly evident across a variety of cancers and viruses, including HIV-1, HTLV-1, Influenza, HCV, Ebola, Vaccinia, PFV-1, LACV, Adenovirus, and SARS-CoV although the mechanisms of action for most of these viruses remains to be determined [11-27]. Indeed, cellular miRNAs are able to silence endogenous retroviruses, sequences which typically share a high degree of homology to present day retroviruses, such as HTLV-1 and HIV-1.

HTLV-1 Tax acts to transactivate the viral long terminal repeat (LTR) through Tax-responsive elements (TREs) in the U3 region. This occurs through transcriptional induction of TREs, posttranslational modifications of TRE-binding factors, and binding with transcription factors. Tax is known to interact with the transcription factors CREB, serum-responsive factor (SRF), and NF- $\kappa \mathrm{B}$ as well as with the cell cycle related proteins Cyclin D2 and D3, mitotic checkpoint regulators (MAD1), cyclin-dependent kinases (cdks), cdk inhibitors $\mathrm{p}^{\mathrm{INK}} 6^{\mathrm{INa}}$ and p21/wafl, and p53 [5,28-43]. Phosphorylation of Tax is necessary for Tax localization in nuclear bodies as well as activation of cellular gene expression through the NF- $\kappa \mathrm{B}$ pathway. Tax activates HTLV-1 transcription through CREB and three CRE enhancer sequences on the LTR. Tax also interacts with $\mathrm{CBP} / \mathrm{p} 300$, which is involved in the formation of the preinitiation complex as well as the p300/CBP-associated factor, P/CAF, which also plays a role in active HTLV-1 gene transcription [37,44-46]. Taken together, HTLV-1 Tax is heavily involved in direct interactions with critical cellular proteins that control not only viral gene expression but also cellular genes involved in tumor formation.

We have previously shown that Tax interacts directly with the cellular $\mathrm{Rb}$ (Retinoblastoma) protein and targets $\mathrm{Rb}$ for degradation via the proteasome pathway, resulting in a decrease in $\mathrm{Rb}$ protein expression in HTLV-1 infected cells and a dysregulation of the cell cycle [47]. Due to the nature of Tax to manipulate and control cellular proteins such as $\mathrm{Rb}$ and overall cell cycle progression, we became interested in determining the effect of HTLV-1 infection and Tax expression on other cellular proteins regulating oncogenesis, including the RNAi pathway. HTLV-1 encodes an additional regulatory protein, called Rex, which has recently been implicated in having RNA silencing suppressor activity. Specifically, Rex interacts with both RNA and Dicer, suppressing Dicer's enzymatic activity [15]. Recently, Tax has been shown to specifically mediate the downregulation of cellular miRNAs which are associated with the regulation of chromatin remodeling factors [48]. Specifically, Tax downregulated miR-149 and miR-873, both of which directly target p300 and P/CAF [48]. This suggests that HTLV-1 infection and its viral transactivators may play a role in dysregulation of the RNAi pathway. Here we show that HTLV-1 infection in the presence of Tax, significantly downregulates Drosha protein expression. We show the in vitro interaction between Tax and Drosha, both in the nucleus and in complex in the presence of proteasome inhibitors. We observe a downregulation of Drosha functionality in the presence of Tax as measured by primary miRNA cleavage. Finally, the changes in cellular miRNA expression in HTLV-1 infected cells can be mimicked in uninfected cells supplementing excess functional Drosha or the addition of antagomiRs against the cellular miRNAs which are downregulated by the virus.

\section{Results}

\section{HTLV-1 Downregulates Core Components of the RNAi Machinery}

Tax acts as the HTLV-1 viral transactivator protein by interacting with various cellular and viral proteins including transcription factors, kinases, and chromatin remodeling proteins, ultimately altering cellular pathways such as apoptosis and the cell cycle to control viral replication and oncogenesis [6-8]. Recently, retroviruses have been shown to control the cellular RNAi pathway in order to evade viral inhibition and also to hijack both the enzymatic and catalytic components of the miRNA machinery. This viral response assists in promoting an active viral infection, or a latent state of infection [11,48-49]. Indeed, other retroviruses such as HIV-1 have been shown to impart a specific suppression of Dicer expression in monocyte-derived-macrophages as compared to T-cells [50]. In order to examine the role HTLV-1 infection has on possible control of the RNAi pathway, we initially screened for the protein levels of core components of the RNAi machinery in HTLV-1 infected cells as compared to uninfected cells. Total protein levels of Drosha, DGCR8, Dicer, Ago2, and $\beta$-Actin were detected in three uninfected T-cell lines, H9, Jurkat, and CEM, as well as in three HTLV-1 infected, Taxpositive T-cell lines, C81, MT2, and MT4 (Figure 1A, lanes 1-3 and lanes 4-6). Drosha protein levels were significantly downregulated in all of the HTLV-1 infected, Tax-positive cells tested when compared to the uninfected cells. Specifically, Drosha is decreased by $62.6 \%$ in C81 cells, $97.3 \%$ in MT2 cells, and $91.5 \%$ in MT4 cells when compared to CEM cells (normalized to $\beta$ Actin). Dicer protein was also slightly downregulated in C81 cells, but more so in MT2 cells when compared to CEM cells (normalized to $\beta$-Actin). Conversely, DGCR8 and Ago2 showed no significant changes in protein level amongst all cell lines screened, suggesting that the downregulation seen for Drosha and Dicer is specific and not a consequence of the entire pathway being inhibited. Interestingly, the protein levels of the core components of the RNAi machinery were also detected in two HTLV-1 infected, Tax-negative cell lines (Figure 1A, lanes 7, 8). Drosha was downregulated by $77.1 \%$ in MT1 cells and $51.3 \%$ in ED- cells as compared to CEM cells (normalized to $\beta$-Actin). We titrated both MT1 and ED- cells in order to determine if this downregulation was an artifact and indeed, with increasing concentrations of protein extract (50, 75, and $100 \mu \mathrm{g})$, Drosha levels also increase (Figure 1B), suggesting that the relative decrease in Drosha is less in HTLV-1 infected, Tax-negative cells as compared to Tax-positive cells. We reproduced these results in HTLV-1 infected $\mathrm{CD}^{+}$primary $\mathrm{T}$-cells (Figure 1C), where Drosha levels are dramatically downregulated as compared to uninfected cells (lane 2 compared to lane 1). In order to rule out the possibility that the loss of Drosha protein is due to a decrease in transcript levels, we performed an RT-PCR of total mRNA isolated from CEM, MT2, ED-, and MT1 cells for Drosha transcripts. In Figure 1D, we show that the Drosha transcript levels are unchanged as compared to GAPDH across all four of these cell lines.

Next, we attempted to mimic this downregulation of Drosha and Dicer by introducing both Tax and HTLV-1 into uninfected 293T cells and screening for core RNAi machinery components. $293 \mathrm{~T}$ cells were transfected with three concentrations $(0.1,1.0$, $10 \mu \mathrm{g}$ ) of plasmids expressing pACH (full-length HTLV-1 clone), pcTax, pACH.M22 (mutated tax gene), or an empty vector control. The pACH.M22 plasmid contains a double amino acid substitution at positions 130 and 131 and eliminates the ability of Tax to transactivate the NF- $\kappa \mathrm{B}$ pathway [51-54]. Cells were 
A)

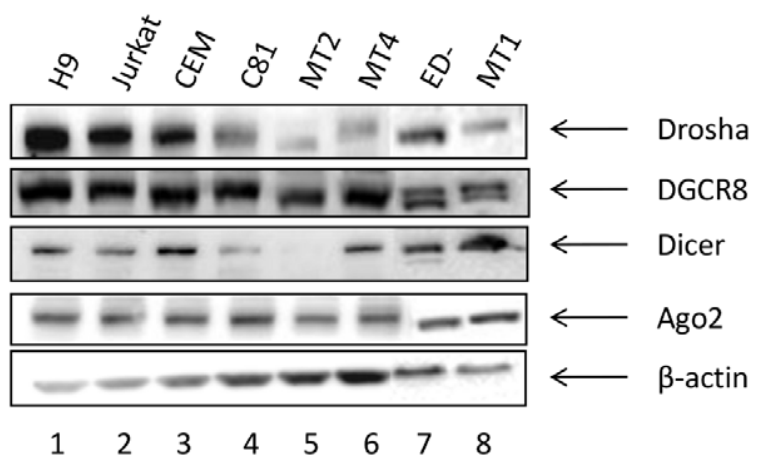

C)

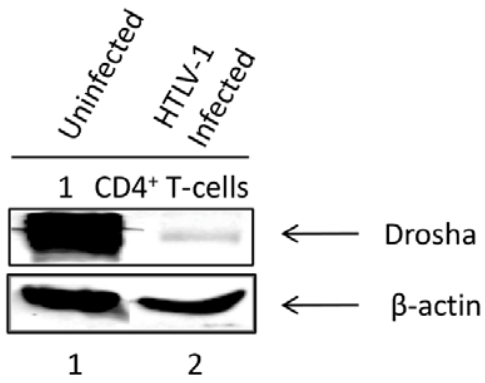

D)

B)

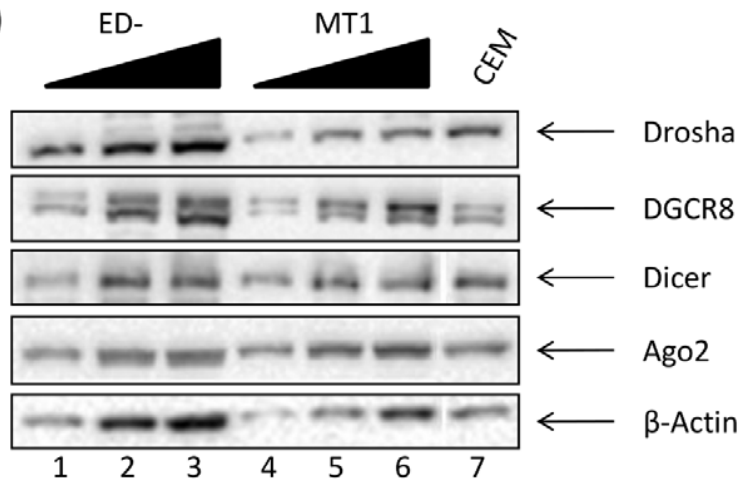

E)

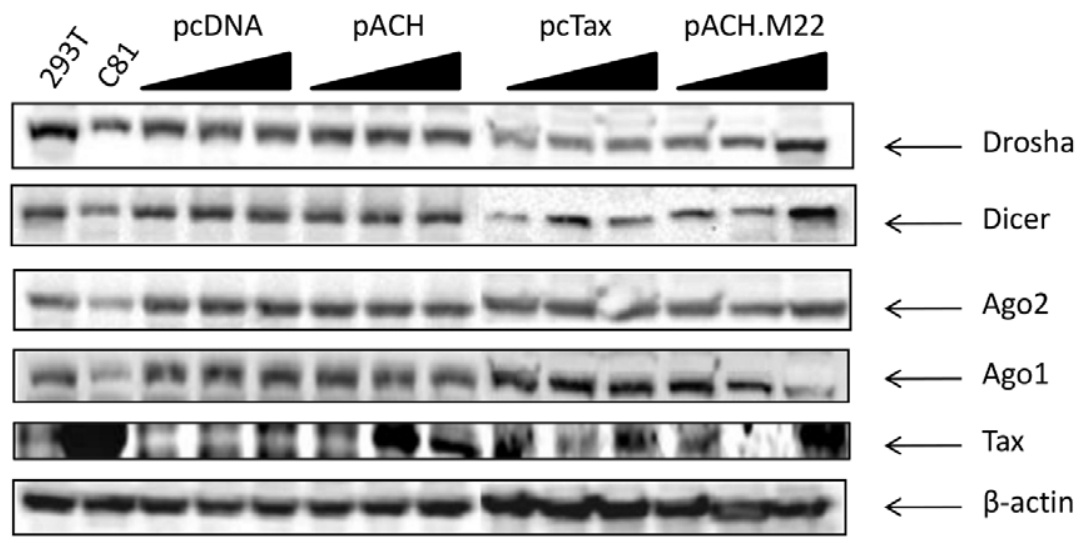

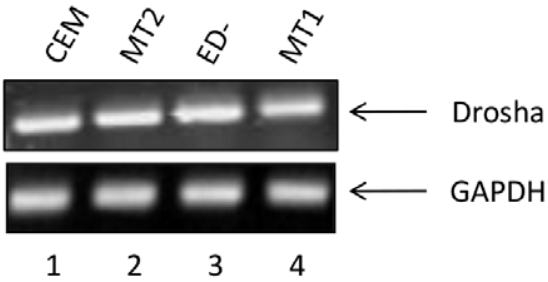

$\begin{array}{llllllllllllll}1 & 2 & 3 & 4 & 5 & 6 & 7 & 8 & 9 & 10 & 11 & 12 & 13 & 14\end{array}$

F)

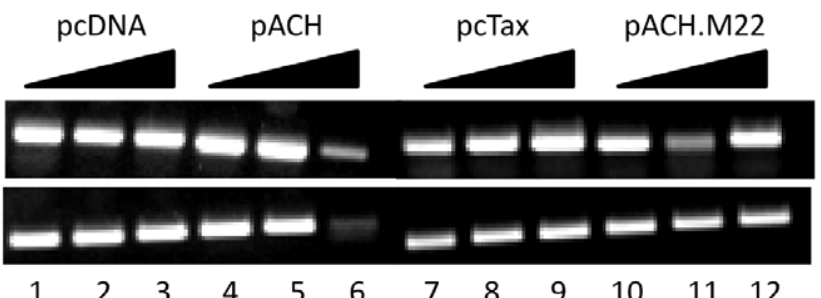

$\longleftarrow$ Drosha

$\longleftarrow$ GAPDH

$\begin{array}{llllllllllll}1 & 2 & 3 & 4 & 5 & 6 & 7 & 8 & 9 & 10 & 11 & 12\end{array}$ 
Figure 1. The RNAi machinery is dysregulated with HTLV-1 infection. A) Uninfected (H9, Jurkat, CEM), HTLV-1 infected, Tax-positive (C81, MT2, MT4), and HTLV-1 infected, Tax-negative (ED-, MT1) T-cell lines were screened for endogenous protein levels of Drosha, DGCR8, Dicer, and Ago2. Seventy-five micrograms of total lysates were used for western blots. Multiple bands for DGCR8 are indicative of isoforms at 86 and $65 \mathrm{kDa}$. $\beta$-Actin serves as a loading control. B) Total lysates of HTLV-1 infected, Tax-negative cell lines ED- and MT1 were titrated (50, 75 and $100 \mu \mathrm{g})$ and screened for endogenous protein levels of Drosha, DGCR8, Dicer, and Ago2. Multiple bands for DGCR8 are indicative of isoforms at 86 and $65 \mathrm{kDa}$. $\beta$-Actin serves as a loading control. C) Whole cell lysates $(50 \mu \mathrm{g})$ from HTLV-1 infected primary CD4 ${ }^{+}$T-cells were run on a $10 \%$ Tris-glycine SDS-PAGE gel and western blotted for Drosha. Data is representative of three independent experiments. $\beta$-Actin serves as a loading control. D) Total RNA was isolated with TRIzol from CEM, MT2, ED-, and MT1 cell lines. RT-PCR was performed for cellular Drosha transcript levels. GAPDH serves as a housekeeping gene loading control. E) Uninfected 293T cells were transfected with pcDNA $(0.1,1.0$, and $10 \mu \mathrm{g}), \mathrm{pACH}(0.1,1.0$, and $10 \mu \mathrm{g})$, pcTax $(0.1,1.0$, and $10 \mu \mathrm{g})$, or pACH.M22 $(0.1,1.0$, and $10 \mu \mathrm{g})$ and were screened for protein levels of Drosha, Dicer, Ago2, Ago1, and Tax. Seventy-five micrograms of total lysates was used for western blots. $\beta$-Actin serves as a loading control. F) Total RNA was isolated with TRIzol from the transfected cells in panel E. RT-PCR was performed for cellular Drosha transcript levels. GAPDH serves as a housekeeping gene loading control. doi:10.1371/journal.pone.0040662.g001

collected 48 hours post-transfection and were western blotted for the presence of Drosha, Dicer, Ago2, Agol, Tax and $\beta$-Actin. Figure $1 \mathrm{E}$ shows endogenous protein levels of core RNAi machinery components in 293T cells transfected with pcDNA and other vectors. Comparing Drosha proteins levels in cell expressing pACH, pcTax, and pACH.M22 to the pcDNA control (lanes 6, 7, 8 and 9, 10, 11 and 12,13, 14 to lanes 2, 3, 4, respectively) results in a $27.5 \%$ decrease in pACH $(10 \mu \mathrm{g})$ expressing cells (lane 8), a $67.3 \%$ decrease in pcTax $(10 \mu \mathrm{g})$ expressing cells (lane 11) and only a $10.4 \%$ decrease in pACH.M22 $(10 \mu \mathrm{g})$ expressing cells. These results imply that in the pACH.M22 mutant Tax expressing cells, we observe close to endogenous levels of Drosha, indicating the downregulation of Drosha may be the result of a functional Tax. Overall, relative expression levels of Dicer, Ago2, and Agol reproduce the data from Figure 1A. The Tax western blot serves as a positive control for Tax expression (lanes 2 and 6-14). The $\beta$-Actin western serves as a positive loading control. Again we confirmed that this decrease in Drosha protein levels is due to Tax expression and not due to an effect on total transcript levels (Figure 1F). Collectively, these data indicate that HTLV-1 infection in the presence of Tax downregulates the RNAi enzyme Drosha in chronically infected cell lines, transfected cells, and primary cells infected with HTLV1 virus.

\section{Colocalization of Tax with Drosha in the Nucleus}

The viral protein Tax has been well documented as interacting directly with multiple critical cellular proteins that control oncogenesis. We sought to determine whether or not Tax interacts with Drosha in order to downregulate and/or signal the Drosha protein for possible degradation. To investigate the potential interaction of Tax and Drosha, we transfected pcTax into HeLa cells and stained the cells 48 hours post-transfection for confocal imaging. We labeled both untransfected and Tax-transfected HeLa cells with antibodies against BRG1, Drosha, Rb, GIT2, and Tax. BRGl and Rb serve as positive Tax-interacting proteins as we have previously shown their intracellular interaction $[1,47]$. BRG1 is constitutively expressed in HeLa cells in the absence of Tax, however post-Tax transfection, BRG1 is found almost exclusively in the nucleus and colocalizes with Tax (Figure 2A). Similarly, Rb is heterogeneously expressed in HeLa cells, however colocalizes with Tax in the nucleus of Tax-expressing cells (Figure 2D). Interestingly, in Tax expressing cells, Drosha is almost exclusively found in the nucleus at specific foci colocalizing with Tax (Figures 2B, G). In order to address possible nonspecific shuttling between the nucleus and the cytoplasm due to transfection conditions or overexpression of Tax, we utilized GIT2 to serve as a negative control for a protein that does not shuttle to the nucleus or colocalize in the presence of Tax (Figure 2E). Therefore, our imaging data show that Tax and Drosha colocalize in the nucleus of Tax-expressing cells.

\section{Drosha is Found in Complex with Tax}

The full length Tax protein contains a variety of domains that impart specific protein-protein interactions as well as interactions with sub-cellular components. The N-terminus of Tax contains both a nuclear localization signal (NLS) as well as a zinc-finger domain which is involved with interactions with cellular transcription factors [31,49,55-57]. Specifically, this domain of Tax is responsible for Tax-mediated CREB transactivation. The C-terminus of Tax is responsible for nuclear-cytoplasmic shuttling and contains a Golgi localization motif, a secretion motif, an LXCXE-like motif, and a PDZ-binding domain [5,47,58-64]. Additionally, the region of Tax between the N- and C-termini includes two leucine zipper motifs used for dimerization as well as activation of $\mathrm{NF}-\kappa \mathrm{B}[5,58-61]$. We have previously shown that Tax is capable of binding to cellular Rb via its LXCXE-like motif [47]. To identify the domain of Tax that binds to Drosha, we performed an in vitro binding assay using full-length Tax and various fragments covering the entire Tax protein fused to GST. Figure 3A shows the results of a GST-Tax pulldown from HeLa whole cell extracts, followed by a western blot for the presence of Drosha. Drosha bound to wild type Tax, but much stronger binding was observed at the $\mathrm{N}$-terminal domain that contained sequence $1-244$. This is partly because the C-terminus may fold back and contain inhibitory activity in an in vitro binding assay. We have also confirmed the interaction of Tax and Drosha in vitro with an immunoprecipitation (IP). We transfected 293T cells with the HTLV-1 clone pACH.Tax $(5 \mu \mathrm{g})$ or pACH.M22 $(5 \mu \mathrm{g})$ mutant Tax in the presence of the proteasome inhibitor PSI $(10 \mu \mathrm{M})$. Our rational for using a proteasome inhibitor was to be able to isolate complexes that were available for biochemical analysis prior to the targeted degradation via the proteosome pathway. We collected cells 48 hours post transfection and lysed whole cell extracts $(\sim 1 \mathrm{mg})$ for an overnight IP with $\alpha$-Tax, $\alpha$-Drosha, or $\alpha$-IgG antibodies. The following day, Protein $A+G$ beads were incubated with the extracts for 2 hours, the beads were washed with low salt buffer, proteins eluted in Laemmli buffer, and were subsequently western blotted for the presence of Drosha. As shown in Figure 3B, Drosha can be successfully IPed out of cells expressing wild type Tax with $\alpha$-Tax in the presence of a proteasome inhibitor (lane 5). 293T cells alone serve as a positive control for the Drosha western blot (lane 1) as well as a positive control for the Drosha IP/western blot (lane 3). Interestingly, the mutant ACH.M22 Tax is unable to interact with Drosha (lane 7). This Tax mutant is only faintly ubiquitinylated and can't interact with the proteasome, therefore indicating that the interaction of Tax and Drosha and the subsequent degradation requires interaction with the proteasome [65]. The $\alpha$-Drosha antibody used for the western blot recognizes all three isoforms of Drosha, corresponding to the molecular weights of 170,156 , and $115 \mathrm{kDa}$, which accounts for the multiple Drosha bands. However, the strongest Tax binding is to the $170 \mathrm{kDa}$ form. A ubiquitin western 


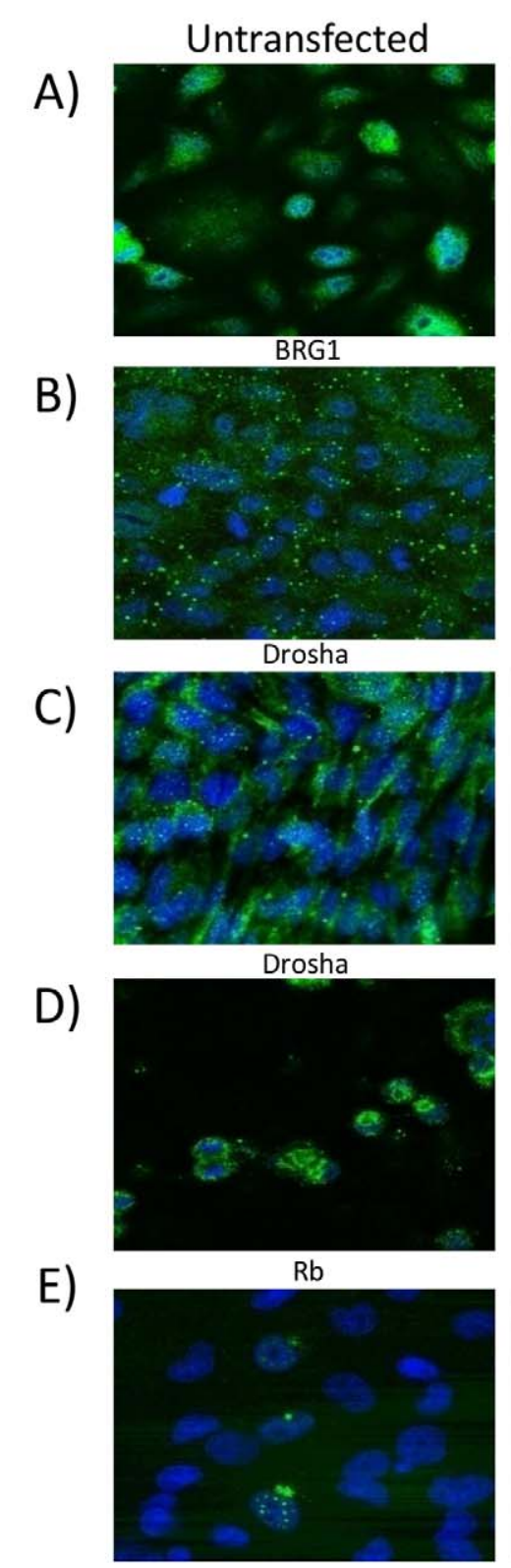

GIT2

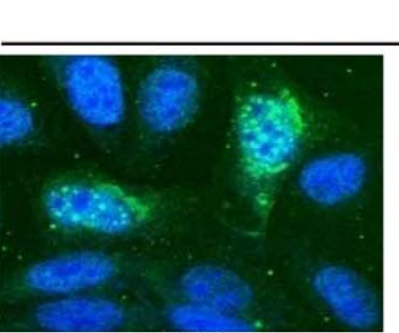

BRG1

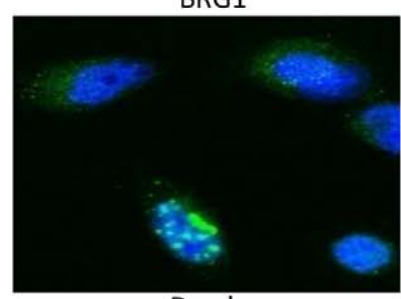

Drosha

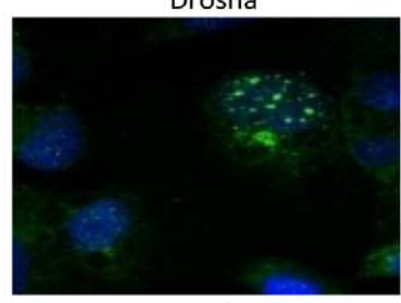

Drosha

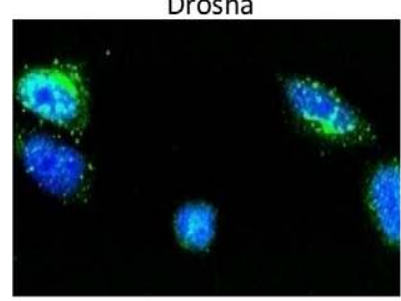

$\mathrm{Rb}$

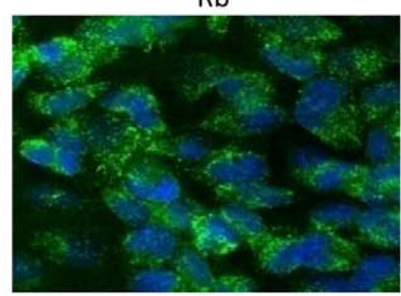

GIT2
Tax Transfected

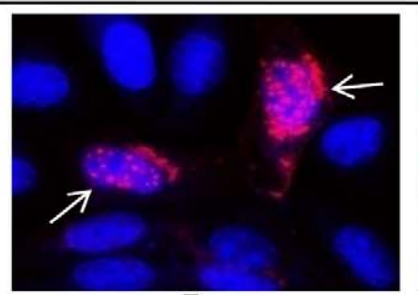

Tax

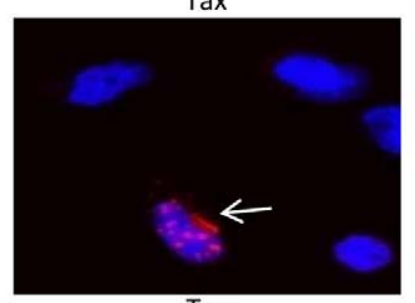

$\operatorname{Tax}$

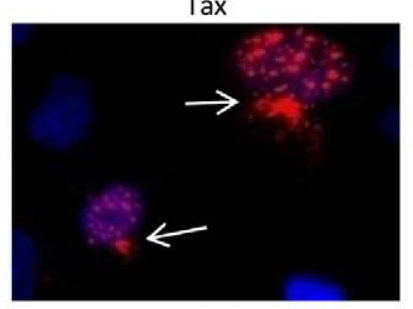

Tax

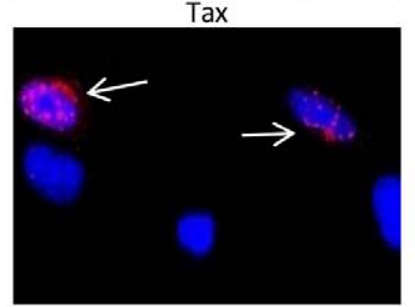

$\operatorname{Tax}$

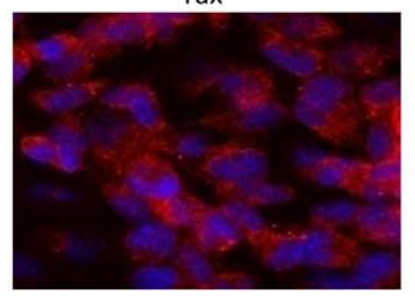

$\operatorname{Tax}$

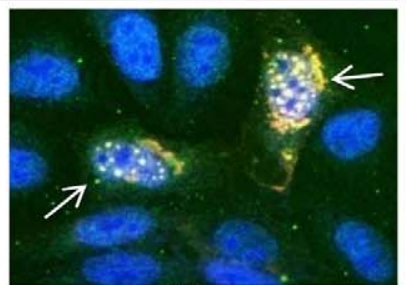

Merge

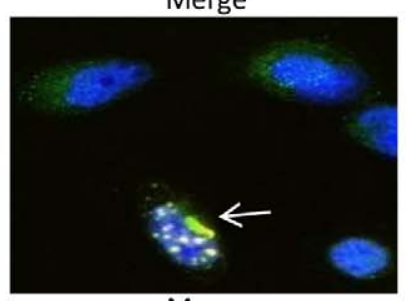

Merge

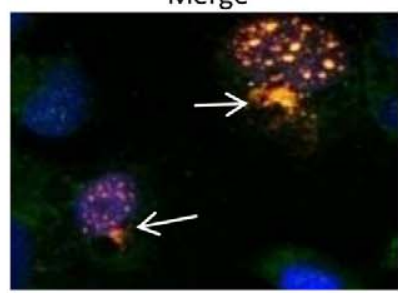

Merge

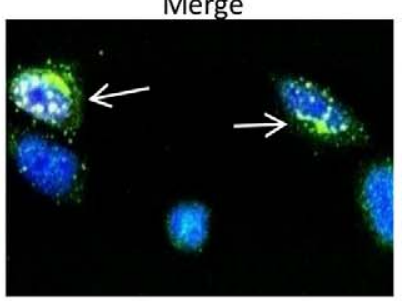

Merge

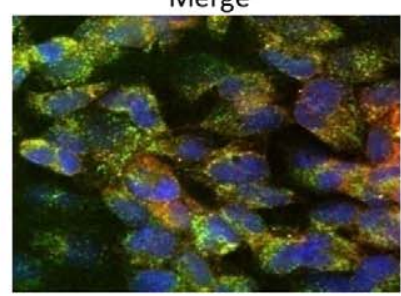

Merge

Figure 2. Nuclear colocalization of HTLV-1 Tax with cellular proteins. HeLa cells were grown on coverslips in the presence or absence of HTLV-1 Tax. Forty-eight hours post transfection of pcTax $(5 \mu \mathrm{g})$, cells were stained for BRG1 (A), Drosha (B, C), Rb (D)), and GIT2 (E) and were visualized with confocal microscopy. Cellular protein staining is represented in green, Tax staining in red, and yellow foci represent colocalization of dual stained cells. Nuclei were stained with DAPI (blue). GIT2 serves as a cytoplasmic protein control.

doi:10.1371/journal.pone.0040662.g002

blot is included as an indication that Drosha is being ubiquitinated in the presence of Tax, however, not in the presence of a Tax mutant (compare lane 5 to lane 7). A summary of relative Drosha binding affinity to Tax constructs from multiple experiments is depicted in Figure 3C. Based on these data, Tax binds to Drosha via the $\mathrm{N}$-terminus (aa 1-244), given that the strongest binding was shown to occur within this region, and can also be identified in complex with Drosha. Collectively, these data indicate that Tax and Drosha interact and can be found in complex in vitro.

Previously, we have shown that the binding of Tax and Rb results in a targeted degradation of $\mathrm{Rb}$ via the proteasome pathway [47]. To investigate whether Tax utilizes a similar mechanism to decrease Drosha protein levels, we designed experiments using proteasome inhibitors. We treated HTLV-1 infected C81 cells with proteasome inhibitors PSI and ALLN (0.1, $1.0,10 \mu \mathrm{M})$. At 48 hours post-treatment, the cells were collected and western blotted for the presence of Drosha. Figure 3D shows the western blot of Drosha normalized to $\beta$-Actin. Both PSI and ALLN treated cells showed an increase in Drosha protein levels concurrent with increasing concentration of proteasome inhibitor. Indeed, the $10 \mu \mathrm{M}$-treated cells show almost a $30 \%$ increase in Drosha protein levels compared to C81 cells alone. All treated cells exhibited no toxicity across three independent experiments (data not shown). This data further indicates that Drosha protein levels 
A)

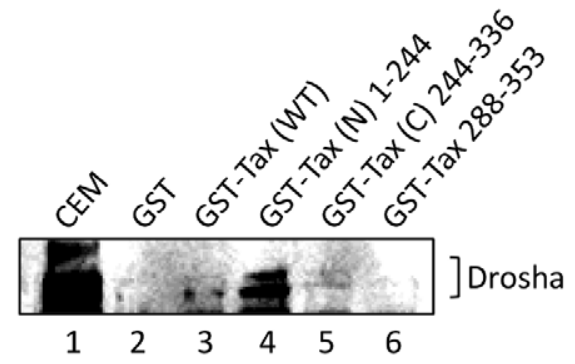

C)

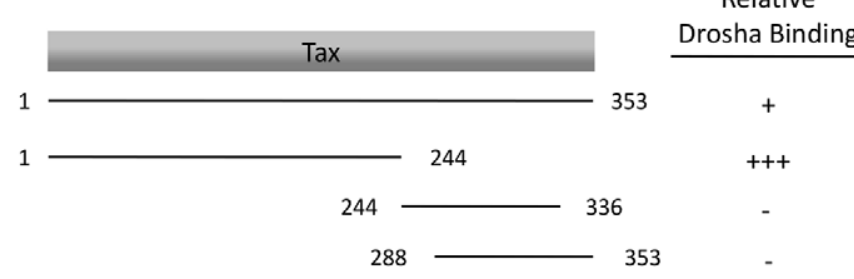

B)

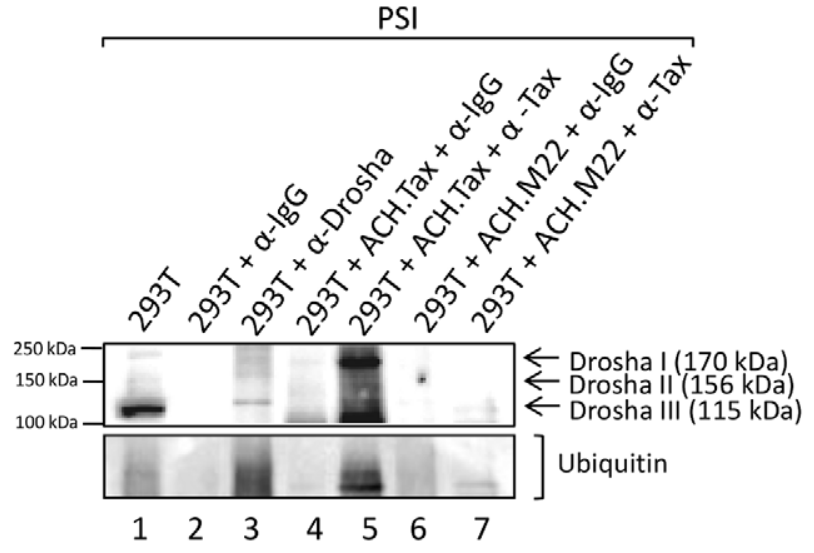

D)

Figure 3. HTLV-1 Tax interacts with Drosha in vitro. A) HeLa whole cell lysates (1 mg) were incubated with purified GST-fusion proteins ( $~ 5 \mu \mathrm{g}$ ) bound to Glutathione-Sepharose beads: GST-Alone, GST-Tax wild type, GST-Tax N-terminus, 1-244, GST-Tax C-terminus, 244-336, and GST-Tax truncated, 288-353. Beads were washed gently, proteins eluted, and western blotted for the presence of Drosha. CEM whole cell extract serves as a positive Drosha control. B) 293T cell lysates were prepared from cells alone or cells transfected with pACH.Tax $(5 \mu \mathrm{g})$ or pACH.M22 $(5 \mu \mathrm{g})$ in the presence of the proteasome inhibitor PSI $(10 \mu \mathrm{M})$. Approximately $1 \mathrm{mg}$ of lysate was incubated with $\alpha$-lgG, $\alpha$-Drosha, or $\alpha$-Tax overnight at $4{ }^{\circ} \mathrm{C}$. The next day, $50 \mu \mathrm{l}$ of a $30 \%$ Protein A + G slurry was used to IP Drosha or Tax and subsequently western blotted for the presence of Drosha and Ubiquitin. Multiple isoforms of Drosha as detected by the antibody are indicated as Drosha I (170 kDa), Drosha II (156 kDa), and Drosha III (115 kDa). C) Graphical depiction of the GST-Tax constructs and the regions which they span for the Tax protein. Relative Drosha binding is based on densitometry counts. D) C81 cells were treated with the proteasome inhibitors PSI and ALLN at increasing concentrations $(0.1,1.0$, and $10 \mu \mathrm{M})$ for 48 hours. Cell lysates were western blotted for the presence of Drosha. $\beta$-Actin serves as a loading control. Drosha recovery as a percentage of CEM Drosha levels is indicated from densitometry counts normalized to $\beta$-Actin using ImageJ.

doi:10.1371/journal.pone.0040662.g003

can be rescued from suppression by HTLV-1 infection with proteasome inhibitors, suggesting that Drosha is targeted by Tax to be degraded via the proteasomal pathway. Collectively, these data point to the regulation of Drosha by direct binding to the Nterminus of Tax and further degradation by the proteasomal pathway.

\section{Tax Prevents Primary miRNA Cleavage by Drosha}

We have shown that Tax and Drosha interact in vitro and that this complex results in a downregulation/degradation of the cellular Drosha protein. This suppression of Drosha is not completely efficient however, as there is still some endogenous Drosha remaining in HTLV-1 infected cells. Here we question whether the remaining Drosha is functional in Tax expressing cells. We utilized a system where we quantify levels of cellular miR326 in Tax transfected cells normalized to a U6 control. We then calculate Drosha functional efficiency as a measure of the relative level of miRNA present versus the relative level of primary transcript, where $100 \%$ is the rate of production in the control. To this end, we transfected $293 \mathrm{~T}$ cells with expression vectors $(1 \mu \mathrm{g})$ for wildtype Tax or the following iterative Tax deletion mutants:

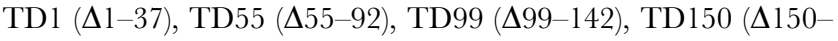
198), TD254 ( $\Delta 254-287)$, or TD319 $(\Delta 319-353)$. We collected the cells 48 hours post-transfection and isolated total RNA by TRIzol extraction. The expression of miR326 was determined by the quantiMiR PCR kit and is shown as a fold change in Figure 4A normalized to U6 and relative to mock transfected control. This data indicates that the Tax D1 mutant and the TaxD55 mutant increase miR326 expression 1.5 and 4 fold, respectively, above basal levels. Interestingly, the Tax mutants spanning from residue 99 to 353 have no functional implications for miR326 expression. These mutants are as functional as the Tax WT, indicating that these regions of deletion are not critical for Drosha function. The significance of the Tax D1 and D55 mutants therefore implies that the regions of Tax deleted in these mutants are necessary for Drosha interaction as well as suppression of function. In order to compare the increase in expression of miR326 to the overall transcript levels in the cell, therefore ruling out non-specificity, we detected primary transcripts encoding miR326 against a region upstream of the miRNA hairpin. These values were normalized to GAPDH and are shown in Figure 4B as a ratio of the relative level of miRNA present over the relative level of primary transcript. The mock transfected cells were set to $100 \%$ efficiency. This data indicates an increase in Drosha efficiency of $100 \%$ over the mock transfected cells with the Tax D1 mutant. The Tax WT vector decreased Drosha functionality by $25 \%$ as compared to the 
control. It is interesting that the Tax Dl mutant increased the efficiency of processing of Drosha 100\%, however, only increased the relative miR326 expression 1.5 fold. These two values are not necessarily proportional as the extrapolation of an active, functional Drosha in the presence of this mutant, does not necessarily have to result in a direct effect on miR326. In Figure 4C we represent a more detailed schematic of the binding domains and motifs of Tax. We depict important binding and interactive regions of Tax with brackets, including the numbered residues. We also depict the cellular proteins with which Tax interacts below each sequence of interest. We propose that Drosha is binding to the N-terminus of Tax, however, more specifically to the region of Tax from 1-92, depicted as the grey shaded area. We have previously confirmed that Tax interacts with the proteasome at residues 23-62, which is also the site of the NLS, Zn finger, as well as the domain involved in CREB activation [47]. This data agrees with the interactions of Tax and Drosha in Figure 3, where the N-terminus of Tax is responsible for Drosha binding. Collectively, these data indicate that the Drosha in Tax-containing and HTLV-1 infected cells is mostly functionally inactive and the functional suppression of Drosha is dependent on its interaction with a small region of the $\mathrm{N}$-terminus of Tax.

\section{Loss of Drosha and DGCR8 Increases Viral Replication}

We have shown above that Drosha is downregulated, degraded, and mostly inactive in HTLV-1 infected cells, however, it was not clear what effect this dysregulation of Drosha would have on viral replication. Here we investigated whether loss of cellular Drosha by siRNA knockdown could affect viral replication. In doing this, it is important to distinguish between a Drosha-specific dysregulation as opposed to an overall disruption of the RNAi pathway, therefore we used siRNA against other RNAi components as a control. We transfected 293T cells with HTLV-1 infectious pACH clone $(5 \mu \mathrm{g})$, and 24-hours post transfection, with siRNAs against Luciferase (150 nM), Drosha (50, 150, $300 \mathrm{nM}$ ), DGCR8 (50, 150, $300 \mathrm{nM}$ ), and Ago2 (50, 150, $300 \mathrm{nM})$. At 72 hours posttransfection, we collected cell culture supernatants and assayed for the presence of virus using an RT (reverse transcriptase) assay. Results of such an experiment are shown in Figure 5A. Here we observed that pACH clone was able to replicate well with the highest concentration of siDrosha and even more dramatic results were obtained with siDGCR8. Interestingly, the loss of DGCR8 across all three concentrations of siRNA resulted in a consistent activation of viral replication. A knockdown of Ago2 did not result in a significant increase in viral replication. Western blot confirmation of the siRNA knockdowns are shown in Figure 5B. In order to determine whether or not the inhibition of Ago2 would result in a decrease in viral fitness and an inhibition of replication, we adopted an alternative approach and treated 293T cells transfected with $\mathrm{pACH}$ with the RISC/Ago2 inhibitor Acriflavine (ACF) $(0.1,1.0$, and $2.5 \mu \mathrm{M})$ [66]. At 72 hours post transfection, we collected supernatants and assayed for the presence of virus via RT assay. We observed that that the efficient, drug inhibition of Ago2 function decreases viral replication at levels comparable to siAgo2 transfection. Collectively, these data indicate that the loss of Drosha and DGCR8 in HTLV-1 infected cells results in an increase in viral replication and its release from the cell.

\section{Suppression of Cellular miRNAs by HTLV-1 can be Rescued by Over Expression of Drosha and Mimicked by antagomiRs}

We were next interested in the regulation and downstream effects of the RNAi pathway in HTLV-1 infected cells. HTLV-1 infection results in a dramatic up (i.e. miR-130b, miR-18a, miR20b) and downregulation (i.e. Let-7i, miR-132, miR-199a) of many host cellular miRNAs [67]. The modulation of these host miRNAs has an effect on the expression of cellular proteins such as p300, NF- $\mathrm{B}$, and BRM, to name a few, which are all recruited by Tax and play a key role in activating HTLV-1 gene transcription [5,30-36,38-40,44-45,56,60,68-71]. To better define the functional significance of Drosha downregulation by Tax, we transfected 293T cells with pACH.Tax $(5 \mu \mathrm{g})$ and 24 hours later added back pGFP-Drosha $(10 \mu \mathrm{g})$. The cells were collected 72 hours later and were lysed $(50 \mu \mathrm{g})$ for western blots of the corresponding downstream proteins, IKK- $\beta$, BRM, and $\beta$-Actin. Here the rationale was that Tax would decrease Drosha levels, resulting in downregulation of miRNA, such as Let7i, miR-199a$3 p$ and miR-132. Downregulation of these miRNAs would in turn effect the translation of mRNAs for genes such as IKK- $\beta$ and BRM (possibly regulated by miR-199a-3p) and other proteins important for HTLV-1 gene expression. Data in Figure 6A shows that transfection of Tax downregulates both IKK- $\beta$ and BRM as compared to the control Drosha add back experiment (compare Lanes 2 and 3). On the other hand, the evidence of Drosha downregulation in the presence of Tax implies the downregulation of cellular miRNAs in response to HTLV-1 infection and subsequent increase in target protein expression. Of particular interest are a set of cellular miRNAs, such as Let-7i, miR-199a-3p, and miR-132 that are downregulated after infection, resulting in an upregulation of cellular proteins that are known to be recruited and utilized by the HTLV-1 promoter. In order to mimic the effect Tax has on cells by sequestering the endogenous miR, therefore allowing for the basal, unchecked expression of these cellular proteins, we transfected $293 \mathrm{~T}$ cells with either Tax or an antagomiR against endogenous cellular miRs which are downregulated with HTLV-1 infection. AntagomiRs used include antihsa-Let-7i to target p50 and p65 miRNA, anti-hsa-miR-132 to target GSK-3 $\beta$ miRNA, and anti-hsa-miR 199a-3p to target IKK$\beta$ and BRM miRNA. Cells were collected 72 hours post transfection and western blots were performed for IKK- $\beta$, p65, p50, GSK-3 $\beta$, and $\beta$-Actin. Results in Figure $6 \mathrm{~B}$ are shown as densitometry counts of western blots for each indicated protein normalized to $\beta$-Actin, plotted as a percent change (measured as arbitrary counts) between antagomiR treated cells and 293T cells alone. These results indicate that there was a dramatic increase of protein expression of IKK- $\beta$, and p65 of approximately 300 and $250 \%$, respectively. There was an approximate $10 \%$ increase in protein levels of p50, GSK-3 $\beta$ and BRM upon antagomiR treatment as compared to cells alone. Collectively, these data indicate that proteins, such as IKK- $\beta$, among others, may directly be regulated by the Tax/Drosha interaction in HTLV infected cells.

\section{Discussion}

HTLV-1 is an oncogenic retrovirus which targets and manipulates common cellular tumor suppressors and signaling pathways in order to establish and maintain a productive infection. Recently, the role of miRNAs in both tumor development and viral infections has provided evidence that the RNAi pathway itself is also targeted by this virus. Indeed, all DNA tumor viruses, with the exception of human papillomaviruses, encode viral miRNAs which modulate tumorigenesis, therefore indicating that the cellular RNAi regulatory pathway is important for viral pathogenesis and control. For example, Epstein Barr Virus (EBV) encodes 25 viral miRNA precursors which are expressed differentially amongst various stages of latency and act to suppress 
A)

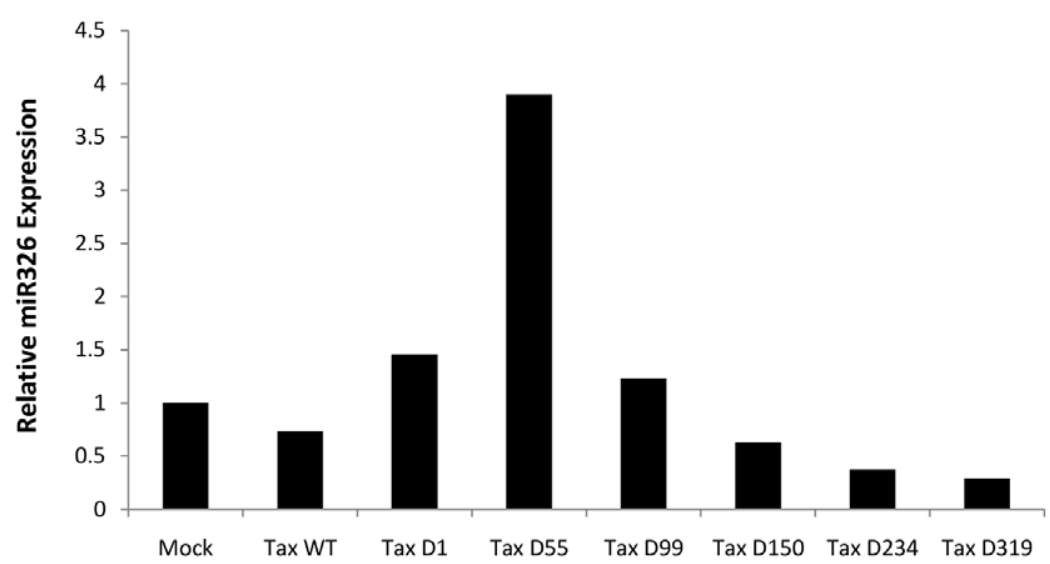

B)

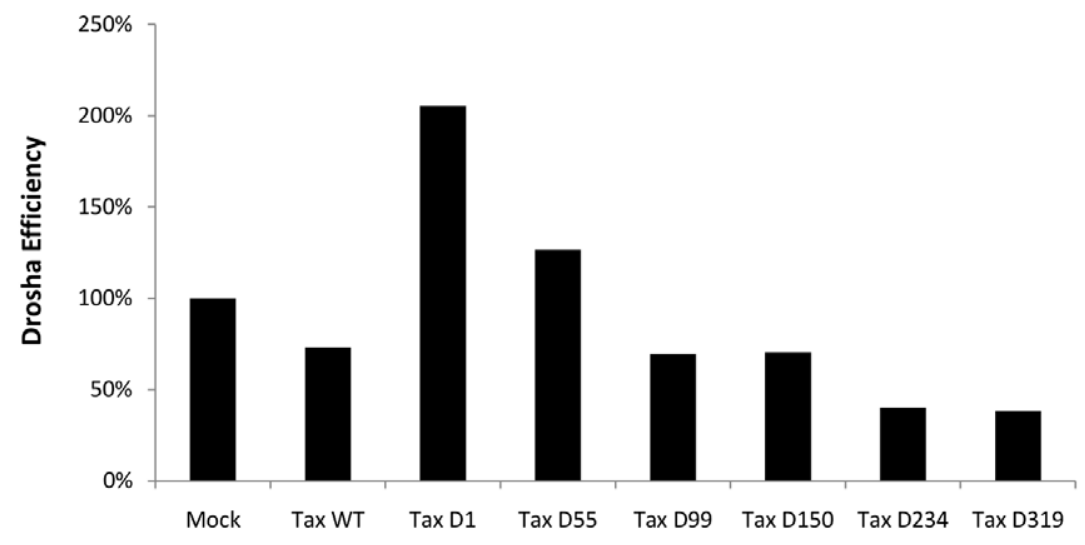

C)
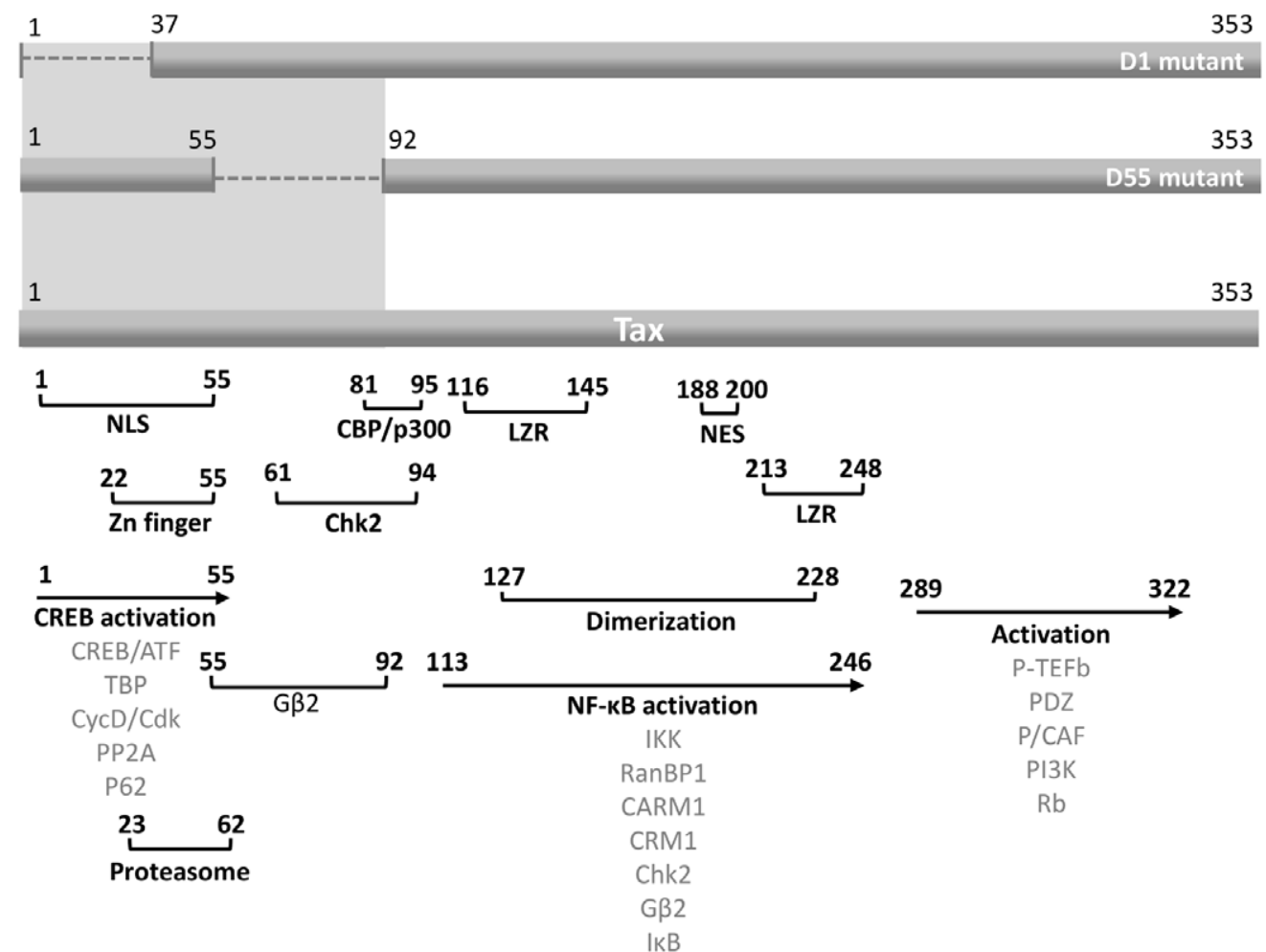
Figure 4. Tax prevents primary miRNA cleavage by Drosha. 293T cells were transfected with Tax expression vectors ( $1 \mu \mathrm{g})$ : Tax WT, TD1 ( $\Delta 1-$

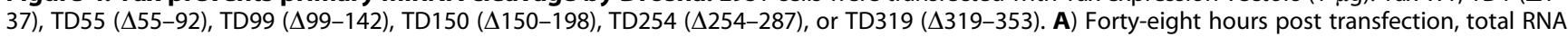
was isolated by TRlzol extraction and expression of miR326 was determined by quantiMiR PCR kit using primers specific to miR326. Values shown are normalized to U6 and shown relative to control. B) Primary transcripts encoding miR326 were detected by RT-qPCR against a region upstream of the miRNA hairpin. Quantities were normalized to GAPDH and efficiency of Drosha processing was determined by charting the expression of mature miRNA over the expression of the primary transcript. Data is shown with the efficiency in the control cells set to $100 \%$. C) A graphical depiction of the Tax mutant constructs TD1 and TD55 with deleted regions and the corresponding domains and motifs of full length Tax. The function of each domain is indicated in brackets and arrows, as well as the associated interacting cellular proteins below each region. The proposed Drosha binding region is indicated by the grey shaded box.

doi:10.1371/journal.pone.0040662.g004

chemokines, inhibit the viral DNA polymerase BALF5, and downregulate the cellular protein PUMA (p53 upregulated modulator of apoptosis) [72-75]. This complex interaction network between viruses and the RNAi pathway can be best described as reciprocal due to host cell miRNAs targeting both cellular and viral transcripts as well as viral miRNAs targeting both cellular and viral transcripts. Additionally, viruses can produce RNA molecules and express proteins which disrupt the cellular RNAi pathway, resulting in either induction or suppression. EBV induces the expression of the cellular miR-155 which assists in the expansion of infected B-cells and promotes their transformation whereas HIV-1 generates both RNA sequences and proteins which suppresses the RNAi pathway. Indeed, HIV-1 has been shown to not only encode its own TAR (trans-activation response region)-derived miRNA which acts as an RNAi decoy, but it also utilizes the viral transactivator Tat as an RNAi suppressor [14,21-22,76-80].

In this study, we characterize the effect HTLV-1 infection has on the cellular RNAi pathway. We have demonstrated that Drosha is downregulated in HTLV-1 infected cell lines, HTLV-1 transfected cells, and infected primary cells. We have also shown that Dicer is downregulated in HTLV-1 infected cell lines only, suggesting that this loss of Dicer could be due to a cell line specific phenomenon and not so much HTLV-1 infection or early stage replication.

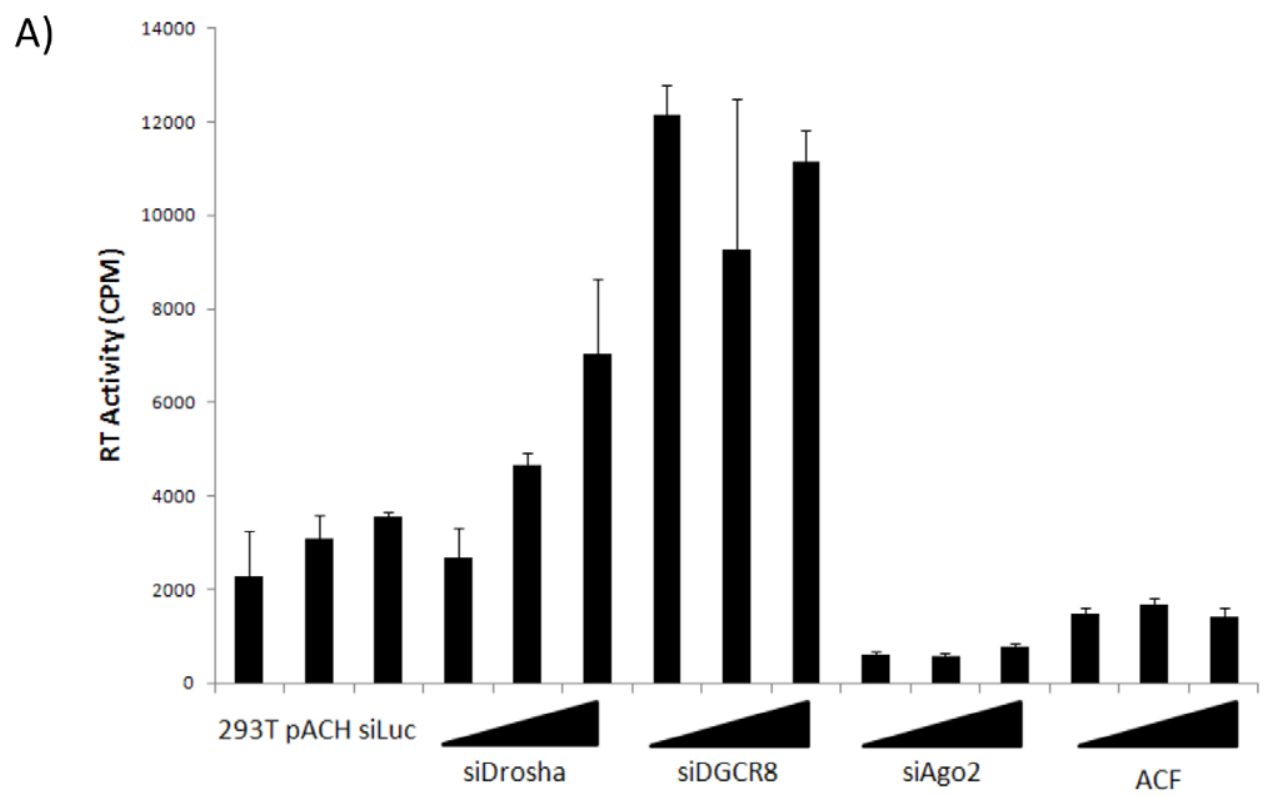

B)

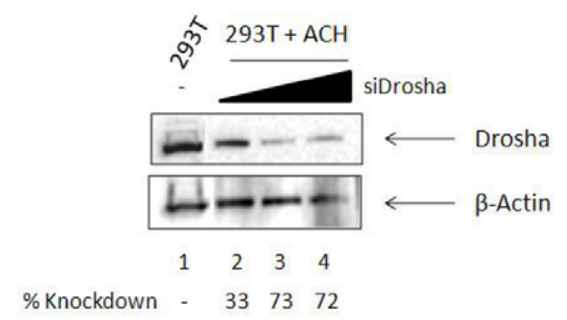

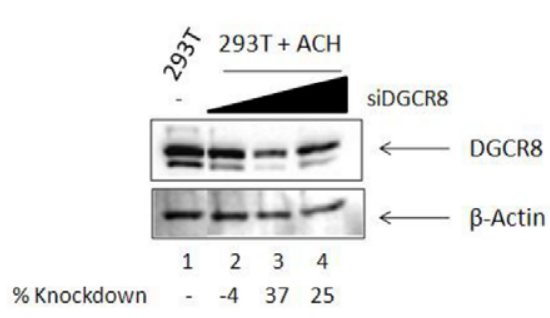

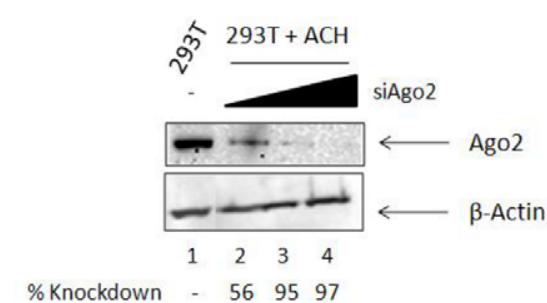

$\%$ Knockdown

Figure 5. Loss of Drosha increases viral replication. A) 293T cells were transfected with HTLV-1 pACH (5 $\mu$ g) and 24 hours later were transfected with siRNAs against Luciferase (150 nM), Drosha (50,150, and $300 \mathrm{nM})$, DGCR8 (50, 150, $300 \mathrm{nM})$, and Ago2 (50, $150,300 \mathrm{nM})$ or were treated with $0.1,1.0$, or $2.5 \mu \mathrm{M}$ Acriflavine (ACF). At 72 hours post-transfection, supernatants were collected and assessed for viral replication by RT (reverse transcriptase) assay. Data was collected in triplicate from at least 2 independent experiments. B) 293T cells from panel A were assayed by western blot for the efficiency of siRNA knockdown of the target proteins. $\beta$-Actin serves as a positive loading control.

doi:10.1371/journal.pone.0040662.g005 

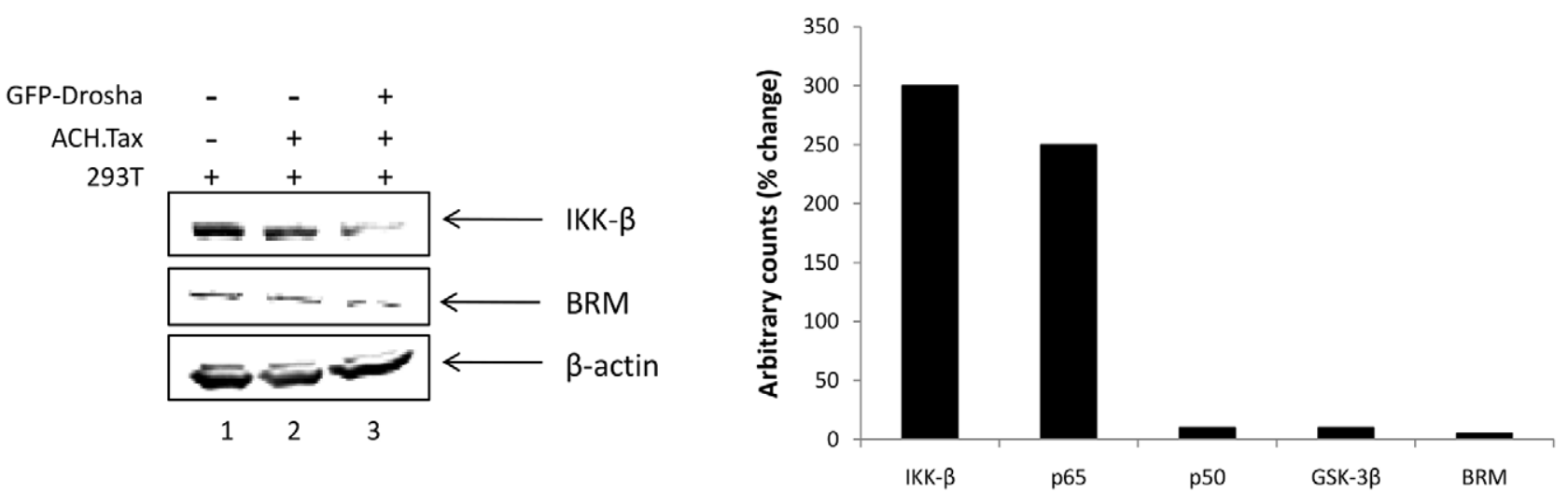

Figure 6. Suppression of endogenous miRNAs dysregulated by HTLV-1. A) 293 Ts were transfected with pACH.Tax (5 $\mu$ g) and 24 hours later were transfected with pGFP-Drosha $(10 \mu \mathrm{g})$. Cells were collected 48 hours post transfection and were western blotted (50 $\mu \mathrm{g})$ for IKK- $\beta$, BRM and $\beta$ Actin. B) 293T cells were transfected with Tax $(5 \mu \mathrm{g})$ or antagomiRs $(100 \mathrm{nM})$ targeting miR-199a-3p, miR-132, or Let7i. Cells were collected 72 hours post transfection, and western blotted $(50 \mu \mathrm{g})$ for IKK- $\beta$, p65, p50, GSK-3 $\beta$, BRM, and $\beta$-Actin. Densitometry counts of western blots for each indicated protein normalized to $\beta$-Actin, plotted as a percent change (measured as arbitrary counts) between antagomiR treated cells and $293 \mathrm{~T}$ cells alone. Densitometry counts were calculated using ImageJ. doi:10.1371/journal.pone.0040662.g006

HTLV-1 gene expression is regulated not only by Tax, but also by the viral protein Rex. Rex induces the expression of HTLV-1 structural proteins post-transcriptionally, by binding to the RxRE (Rex-responsive element) on the U3 region of the HTLV-1 LTR (long-terminal repeat) [81-83]. Recently, Rex has been shown to suppress the RNAi pathway by interacting with cellular Dicer, inhibiting the conversion of shRNA to siRNA [15]. As we have shown that Drosha is downregulated not only with HTLV-1 infection, but specifically in the presence of Tax, therefore we hypothesized that Tax could be interacting directly with Drosha. Tax-transfected HeLa cells show distinct, punctate foci in the nucleus when stained with antibodies against both Tax and Drosha in independent experiments. We observed that Tax and Drosha colocalize distinctly, however it is important to note that this HTLV-1-dependent downregulation of Drosha is not completely efficient, and that there is still some endogenous Drosha remaining in these cells. This is analogous and similar to the colocalization of cellular $\mathrm{Rb}$ and Tax in cells (Figure 2D) as we have previously shown that Tax binds directly to $\mathrm{Rb}$ and is a necessary interaction for the subsequent degradation of $\mathrm{Rb}$ in vitro [47]. We next demonstrated that Drosha can be found in complex with Tax at the $\mathrm{N}$-terminus, specifically at the region spanning aa 1-244. Within this N-terminal region of Tax, we observed two potential motifs that could be utilized for this interaction, the Zinc finger motif and the leucine-zipper-like region. The $\mathrm{N}$-terminus of Tax is most commonly known for the CREB (cAMP-responsive element-binding)-transactivation domain where the transcription factors p300/CBP, and p/CAF (p300/CBP-associated factor) bind and promote viral transcription from the LTR [56]. We have specifically shown the interaction of Drosha and Tax with an immunoprecipitation of Drosha from Tax-expressing cells in the presence of proteasome inhibitors. We indicate that this interaction is not seen when a cell is expressing the Tax mutant, ACH.M22. Interestingly, the N-terminus portion of Tax is also known to interact with the proteasome, therefore this dual binding allows Tax to bring Drosha in close proximity with the proteasome complex, resulting in the degradation of Drosha. This proteasomal degradation is confirmed by a $50 \%$ recovery of total Drosha protein levels in HTLV-1 infected cells when treated with proteasome inhibitors PSI (cbz-ile-glu-(O-t-Bu)-ala-leucinal) and ALLN ( $\mathcal{N}$-acetyl-leu-leu-norleucinal). These proteasome inhibitors have also been well documented as anticancer and antiagiogenic therapeutics. Furthermore, a number of colleagues in the field have shown that proteasome inhibitors such as PS-341 or bortezomib can in fact downregulate HTLV-1 levels, resulting in a decrease of T-cell leukemia cells [84-88]. This is consistent with our siDrosha and proteasome inhibitor data, where a drug/ peptide inhibitor can regulate miRNA machinery by increasing proteins such as Drosha resulting in an increased host cellular RNAi response against HTLV-1 activity.

Three large studies have recently examined the dysregulation of cellular miRNAs in both HTLV-1 infected cell lines and ATLL samples, resulting in surprisingly little overlap [67,89-91]. These studies do however provide a large pool of upregulated and downregulated cellular miRNAs from which to pull functional data in the context of HTLV-1 infection. We show here, that in the presence of Tax, endogenous Drosha is less functional and not as efficient in processing miRNAs. Drosha efficiency, as measured by the processing of endogenous miR326 as compared to overall levels of transcript, was highest in the presence of N-terminal Tax deletion mutants from residues 1-92. This again indicates that the interaction between Tax, Drosha, and the proteasome occurs on the N-terminal region of Tax.

We also show that in the absence of Drosha, HTLV-1 viral replication increases by at least two-fold. The knockdown of DGCR8 also resulted in a significant increase in HTLV-1 replication, suggesting a dysregulation of the microprocessing complex. The downregulation of HTLV-1 replication with Ago2 knockdown was validated with a comparable downregulation when cells were treated with the RISC inhibitor ACF.

We suggest that HTLV-1 dysregulates the RNAi pathway, including up- and down-regulation of cellular miRNAs by inhibiting the function of and degrading Drosha, resulting in a modulation of tumor and viral suppressing cellular functions. One miRNA upregulated in HTLV-1 infection, miR-146a, can be activated by Tax through an NF- $\kappa \mathrm{B}-$ dependent pathway. This 
miRNA, however, has been experimentally shown to both interfere with HTLV-1 infected cell growth, as well as stimulate infected cell growth upon overexpression [90]. Overexpression of miR146a appears to favor the proliferation of an HTLV-1 infected cell population, however this effect is not always reproducible [67]. Due to the nature of the control of miRNA production in HTLV-1 infection, it is not surprising to observe an increase in viral replication in the absence of Drosha, due likely to the downregulation of a cellular miRNA that would otherwise suppress viral replication. In order to investigate the control of miRNA production in HTLV-1 cells, we analyzed the pool of published downregulated miRNAs for those that target cellular proteins known to interact with Tax and regulate transcription. Our rationale here was that if HTLV-1 infection downregulates a particular miRNA which targets a cellular protein necessary for Tax transactivation, we could mimic this interaction by introducing an antagomiR into uninfected cells, therefore disabling the endogenous miRNA and increasing protein expression. Based on three recent studies which examined expression changes of cellular miRNAs in HTLV-1 infected cell lines, we selected the downregulated miRNAs, miR-199a, miR-132, and miR-Let7i for further analysis $[67,89-90,92]$. In ovarian cancer cells, miR$199 a-3 p$ has been shown to regulate IKK- $\beta$ to affect NF- $\kappa$ B activity as well as targeting the SWI/SNF subunit BRM in a variety of human cancers [93-94]. Upon KSHV (Kaposi's sarcoma-associated herpesvirus) infection, as well as HSV-1 (herpes simplex virus-1) and HCMV (human cytomegalovirus) infection, miR-132 is upregulated and regulates the transcriptional co-activator p300 [95]. Following microbioal infection of Cryptosporidium parvum, miR-Let7i forms an inducible silencing complex with the NF- $\mathrm{KB}$ p50 subunit [96]. Confirming this rationale in the scope of HTLV-1 infection, we observed a increase in IKK- $\beta$ and BRM protein levels in the presence of Tax and an opposite effect upon overexpression of functional Drosha. We observed an increase in cellular levels of IKK- $\beta$, p65, p50, GSK-3 $\beta$, and BRM upon treatment with antagomiRs against the above downregulated miRNAs as compared to cells alone, indicating that the antagomiRs mimic the cellular protein expression seen in Tax-expressing cells. Tax plays a major role in the activation of cellular NF-кB, however, HTLV-1 infected cells also develop Taxindependent activation of NF- $\mathrm{KB}$. This delicate balance between activation and suppression of these cellular genes via the manipulation of the RNAi pathway by HTLV-1 infection strongly supports the notion that dysregulation of Drosha and other core components of the RNAi machinery control the rate of infection and T-cell transformation.

\section{Materials and Methods}

\section{Cell Culture}

Uninfected T-cell lines H9, Jurkat, and CEM cells as well as HTLV-1 infected, Tax-positive T-cell lines C81, MT2, and MT4 were obtained from the NIH AIDS Research and Reference Reagent Program. HTLV-1 infected, Tax-negative cell lines were a generous gift from Dr. Cynthia Pise-Masison (NCI/NIH, Bethesda, MD). HeLa cervical carcinoma cell line and 293T endothelial kidney cells were obtained from ATCC (Manassas, VA). Primary CD4+ T-cells (\#2W-200, Lonza, Allendale, NJ) infection were a generous gift from Dr. Pooja Jain (Drexel University College of Medicine, Doylestown, PA). Suspension cell lines were maintained in RPM1-1640 media containing 10\% FBS, $1 \%$ L-glutamine, and 1\% streptomycin/penicillin (Quality Biological) at $37^{\circ} \mathrm{C}$ in $5 \% \mathrm{CO}_{2}$. Adherent cell lines were maintained in DMEM containing 10\% FBS, $1 \%$ L-Glutamine, and $1 \%$ streptomycin/penicillin (Quality Biological) at $37^{\circ} \mathrm{C}$ in $5 \% \mathrm{CO}_{2}$.

\section{Antibodies and siRNA}

Antibodies used for confocal microscopy are as follows: $\alpha-B R G 1$ (sc-10768), $\alpha$-Rb (sc-74562), and $\alpha$-GIT2 (sc-5416) were obtained from Santa Cruz Biotechnology, Inc. (Santa Cruz, CA), $\alpha$-Drosha (ab12286) was obtained from Abcam (Cambridge, MA), $\alpha$-Tax was generated in house, and AlexaFluor 488 Goat-anti-Rabbit (A11008), AlexaFluor 660 Donkey-anti-Rabbit (A21083), and AlexaFluor 568 Goat-anti-Mouse (A11004) were obtained from Invitrogen (Carlsbad, CA). Antibodies used for western blotting are as follows: $\alpha$-Drosha (ab12286), $\alpha$-DGCR8 (ab82876), $\alpha$-Dicer (ab14601), $\alpha$-Ago2 (ab57113), and $\alpha$-Agol (ab5070-100) from Abcam (Cambridge, MA), $\alpha$-Tax was generated in house, $\alpha$-Actin (sc-1615), $\alpha$-Ubiquitin (sc-9133), $\alpha$-p65 (sc-7151), $\alpha$-p300 (sc-585), and $\alpha$-IKK- $\beta$ (sc-7329) were obtained from Santa Cruz Biotechnology, Inc. (Santa Cruz, CA), and $\alpha$-GSK-3 $\beta$ (27C10) was obtained from Cell Signaling (Beverly, MA). SiRNA against Luciferase (D-002050-01-20) was obtained from Thermo Scientific (Rockford, IL) and siRNA against siDrosha (GS29102), siDGCR8 (GS54487), and siAgo2 (GS27161) were obtained from Qiagen (Valencia, CA).

\section{Electroporations/Transfections}

$293 \mathrm{~T}$ cells were transfected with plasmid DNA according to Attractene lipid reagent recommended protocols (Qiagen, Valencia, CA). Briefly, 293T cells at $2.5 \times 10^{5}$ cells were plated in DMEM $^{+/+/+}(500 \mu$ l, with serum, with L-glutamine, with penicillin/streptomycin) in a 24-well plate. A reaction mixture containing pcDNA, pACH, pcTax, or pACH.M22 (0.1, 1.0, or $10 \mu \mathrm{g})$ plasmid DNA was incubated with Attractene reagent $(3 \mu \mathrm{l})$ in $\mathrm{DMEM}^{-1-1-}(100 \mu \mathrm{l}$, without serum, without L-glutamine, without penicillin/streptomycin). The reaction mixture was incubated for $20 \mathrm{~min}$ at $25^{\circ} \mathrm{C}$ and then added dropwise onto the cells. Cells were collected 48 hours post-transfection. Lipid transfections of pcTax, pACH, and siRNA were performed according to Attractene and Lipofectamine RNAiMax (Invitrogen, Carlsbad, CA) lipid reagent recommended protocols (Qiagen, Valencia, CA). Briefly, $2.5 \times 10^{5}$ cells were plated in DMEM $^{+/+/+}$ $(500 \mu \mathrm{l})$ in a 24 -well plate. A reaction mixture containing $\mathrm{ACH}$ DNA $(5 \mu \mathrm{g})$ was incubated with Attractene reagent $(3 \mu \mathrm{l})$ in $\mathrm{DMEM}^{-\rho-/-}(100 \mu \mathrm{l})$. The reaction mixture was incubated for $20 \mathrm{~min}$ at $25^{\circ} \mathrm{C}$ and then added dropwise onto the cells. At 24 hours post-transfection, a reaction mixture containing siLuc (150 nM), siDrosha (50, 150, $300 \mathrm{nM})$, siDGCR8 (50, 150, $300 \mathrm{nM}$ ) or siAgo2 (50, $300 \mathrm{nM})$, was incubated with RNAiMax reagent $(1.5 \mu \mathrm{l})$. The reaction mixture was incubated for $20 \mathrm{~min}$ at $25^{\circ} \mathrm{C}$ and then added dropwise onto the cells. Lipid transfections of the Tax expression vectors (Tax WT, TD1 $(\Delta 1-37)$, TD55

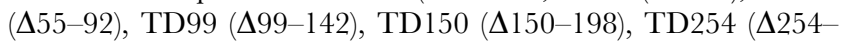
$287)$, or TD319 ( $\Delta 319-353))$ were performed in 6 -well plates according to Lipofectamine 2000 recommended protocols (Invitrogen, Carlsbad, CA). Lipid transfections of pACH.Tax $(5 \mu \mathrm{g})$, pACH.M22 $(5 \mu \mathrm{g})$, and pGFP-Drosha $(10 \mu \mathrm{g})$ were performed with Attractene as indicated above. The wild-type pEGFPC1_Drosha expression vector was kindly provided by Dr. Bharat Ramratnam (Warren Alpert Medical School, Brown University, Providence, RI).

\section{Confocal Microscopy}

HeLa cells were grown on coverslips for $48 \mathrm{hrs}$ post pcTax transfection. Cells were fixed with $4 \%$ paraformaldehyde for one hour. Cells were permeabilized with Triton X-100 in PBS $(0.5 \%)$ 
for 20 min and washed with PBS without $\mathrm{Ca}^{2+}$ and $\mathrm{Mg}^{2+}$. Cells were blocked at $25^{\circ} \mathrm{C}$ for $10 \mathrm{~min}$ with Goat Serum (3\%) in PBS without $\mathrm{Ca}^{2+}$ and $\mathrm{Mg}^{2+}$. Cells were incubated with primary antibody (1:200) in Goat Serum (3\%) for one hour, in the dark, at $37^{\circ} \mathrm{C}$. Cells were washed $3 \times$ with PBS without $\mathrm{Ca}^{2+}$ and $\mathrm{Mg}^{2+}$ and secondary antibodies were added (1:50) in Goat Serum (3\%) for one hour, in the dark, at $37^{\circ}$. Cells were washed $3 \times$ with PBS without $\mathrm{Ca}^{2+}$ and $\mathrm{Mg}^{2+}$ and a sufficient volume of DAPI working solution was added to completely cover the sample, incubating for 2-10 min, in the dark, at $25^{\circ} \mathrm{C}$. Coverslips were washed to remove excess DAPI and mounted onto a slide with Fluoromount G $(10 \mu \mathrm{l}$, Southern Biotech, Birmingham, AL). Cells were imaged with a Zeiss LSM 710 Confocal System (George Washington University, Center for Microscopy and Image Analysis).

\section{Western Blotting}

Cells were collected from culture and spun at 1,800 rpm, for $5 \mathrm{~min}$, at $4^{\circ} \mathrm{C}$, and pellets were washed twice with phosphate buffered saline (PBS) without Ca2+ and Mg2+ (Quality Biological). Cell pellets were resuspended in lysis buffer $(50 \mathrm{mM}$ Tris$\mathrm{HCl}, \mathrm{pH} 7.5,120 \mathrm{mM} \mathrm{NaCl}, 5 \mathrm{mM}$ EDTA, $0.5 \%$ NP-40, $50 \mathrm{mM} \mathrm{NaF}, 0.2 \mathrm{mM} \mathrm{Na} 3 \mathrm{VO} 4,1 \mathrm{mM}$ DTT, one complete protease cocktail tablet $/ 50 \mathrm{~mL}$ ) and incubated on ice for $20 \mathrm{~min}$, with gentle vortexing every $5 \mathrm{~min}$. Cell lysates were centrifuged at $10,000 \mathrm{rpm}$ for $10 \mathrm{~min}$. Protein concentrations were determined using Bradford protein assay (Bio-Rad, Hercules, CA). Cell extracts were loaded $(50-75 \mu \mathrm{g})$ on a $4-20 \%$ SDSPAGE gel, run at $200 \mathrm{~V}$, and transferred onto nitrocellulose membranes. Membranes were blocked with PBS containing $0.1 \%$ Tween-20 and milk (5\%), and incubated overnight at $4{ }^{\circ} \mathrm{C}$ with the appropriate primary antibody. Membranes were incubated with the appropriate secondary antibody and developed next day. Whole cell extracts from $\mathrm{CD}^{+}$primary $\mathrm{T}$-cells were prepared using M-PER Mammalian Protein Extraction Reagent (Pierce, USA). Cell debris was cleared from the lysates by centrifugation (5 min, 14,000 g). Protein concentrations were determined using Bradford protein assay (Bio-Rad, Hercules, CA). Cell lysates were resolved by SDS-PAGE and transferred to a PVDF membrane. The blots were blocked for $1 \mathrm{~h}$ with Odyssey blocking buffer (Licor, Lincoln, NE) and rinsed with PBST (PBS +0.05\% Tween$20)$, once for $10 \mathrm{~min}$ and twice for $5 \mathrm{~min}$. The membranes were then incubated with either $\alpha$-Drosha $(1: 1000)$ or $\alpha$-Actin $(1: 2000)$ monoclonal antibodies (Abcam, Cambridge, MA), for 2 hours at room temperature, rinsed with PBST (once for $10 \mathrm{~min}$ and twice for $5 \mathrm{~min}$ ), and incubated for 1 hour with an $\alpha$-rabbit and $\alpha$-mouse secondary antibody (Licor, Lincoln, USA) conjugated to IRDy800 and IRDy680 respectively. Signals were detected by Licor Pearl Pulse Imager. Densitometry was performed using Image J software (Wayne Rasband, NIH, USA).

\section{Proteasome Inhibitor Treatments}

C81 HTLV-1 infected cells were plated at a density of $1 \times 10^{6}$ cells/well in a 12-well plate. Cells were treated with three concentrations $(0.1,1.0$, and $10 \mu \mathrm{M})$ of the proteasome inhibitors ALLN (208750), and PSI (539160) obtained from EMD4Biosciences (San Diego, CA). Cells were collected 48 hours post treatment, washed, lysed, and Western blotted for Drosha and $\beta$ Actin. Alternatively, 293T cells were treated with $10 \mu \mathrm{M}$ of PSI and 24 hours later were transfected with the indicated expression vectors (pACH.Tax or pACH.M22). Cells were collected, washed, lysed, and prepared for immunoprecipitation.

\section{RT-PCR}

Total RNA was isolated from the indicated cell types using the TRIzol protocol (Invitrogen, Carlsbad, CA). From total RNA, $2 \mu \mathrm{l}$ of RNA was used for the cDNA synthesis reaction using iScript (Bio-Rad, Hercules, CA). The newly synthesized cDNA was used as the template for a PCR reaction for Drosha (TGCAACTGGTAGGGACAGAG, ACAGTGGTGAAGGTGGGATT) and GAPDH

(GGAAGGTGAAGGTCGGAGTCAA, CCTTGACGGTGCAATGGAAT). Expression of miR326 was determined by the quantiMiR PCR kit (SBI, Mountainview, CA) using the miR326 detection (sense) primer: CCTCTGGGCGCTTCGTCGAG. Primary transcripts encoding miR326 were detected by RT-qPCR (CACCAACATCGTAGCGCAAACG, AAGTGAGAACGGGGAAGCAAG).

\section{Immunoprecipitation}

Cell extracts from 293T cells alone, cells transfected with pACH.Tax $(5 \mu \mathrm{g})$, or pACH.M22 $(5 \mu \mathrm{g})$ were collected as described above. Whole cell extracts $(\sim 1 \mathrm{mg})$ were incubated overnight, rotating, at $4{ }^{\circ} \mathrm{C}$ with $\alpha$-IgG, $\alpha$-Drosha, or $\alpha$-Tax. The next day, $50 \mu \mathrm{l}$ of a $30 \%$ slurry of Protein A+G beads (Calbiochem, Rockland, MA) was added to the IPs and incubated for two hrs, rotating, at $4^{\circ} \mathrm{C}$. The IPs were spun briefly and beads were washed $1 \times$ with $\mathrm{TNE}_{150}+0.1 \% \mathrm{NP}-40$, followed by a $1 \times$ wash with $\mathrm{TNE}_{50}+0.1 \%$ NP-40. Proteins were eluted off of the beads with Laemmli buffer, run on a gel, and western blotted for both Drosha and Ubiquitin.

\section{Reverse Transcriptase Assay}

Supernatants were collected at indicated time points to test for the presence of virus. Viral supernatants $(10 \mu \mathrm{L})$ were incubated in a 96-well plate with a $\mathrm{RT}$ reaction mixture containing $1 \times \mathrm{RT}$ buffer (50 mM Tris-HCl, $1 \mathrm{mM}$ DTT, $5 \mathrm{mM} \mathrm{MgCl}_{2}$, and $20 \mathrm{mM} \mathrm{KCl}), 0.1 \%$ Triton-X100, poly (A) (1 U/mL), poly d(T) $(1 \mathrm{U} / \mathrm{mL})$, and $\left[{ }^{3} \mathrm{H}\right] \mathrm{TTP}$. The mixture was incubated overnight at $37^{\circ} \mathrm{C}, 5 \mu \mathrm{l}$ of the reaction mix was spotted on a DEAE Filtermat paper, washed four times with $5 \% \mathrm{Na}_{2} \mathrm{HPO}_{4}$, three times with water, and then dried completely. RT activity was measured in a Betaplate counter (Wallac, Gaithersburg, MD). Data is shown as cpms (counts per minute).

\section{GST-Pulldown}

HeLa whole cell extracts $(1 \mathrm{mg})$ were prepared and incubated with $10 \mathrm{ug}$ of the following GST-Tax constructs bound to glutathione-sepharose beads: GST-Tax wildtype, GST-Tax 1244 (N-terminus), GST-Tax 244-336 (C-terminus), and GST-Tax 288-353. Extracts were brought up to $500 \mu \mathrm{l}$ in $\mathrm{TNE}_{50}+0.1 \% \mathrm{NP}-$ 40 (100 mM Tris-HCl, pH 7.5; $50 \mathrm{mM} \mathrm{NaCl;} 1 \mathrm{mM}$ EDTA; $0.1 \%$ NP-40) buffer and incubated overnight at $4{ }^{\circ} \mathrm{C}$ with rotation. The following day, samples were spun and washed twice with $\mathrm{TNE}_{150}+0.1 \%$ NP-40 (100 mM Tris, pH 8.0; $300 \mathrm{mM} \mathrm{NaCl}$; $1 \mathrm{mM}$ EDTA, $0.1 \% \mathrm{NP}-40$ ) buffer and $1 \times$ with $\mathrm{TNE}_{50}+0.1 \%$ NP-40 to remove nonspecifically bound proteins. Samples were loaded and run on a 4-20\% Tris-Glycine SDS-PAGE gel and subjected to Western blotting for the presence of Drosha.

\section{AntagomiR Experiments}

AntagomiRs were obtained from Qiagen as follows: miScript miRNA inhibitor Anti-hsa-let-7i (Catalog \# MIN0000415), Antihsa-miR-199a-3p (Catalog \# MIN0000232), and Anti-hsa-miR132 (Catalog \#MIN0000426). AntagomiRs were transfected into 293T cells using Attractene as described above. Briefly, 293T cells were plated at $1 \times 10^{5}$ cells/well in a 6 well plate. AntagomiRs were 
incubated in DMEM ${ }^{-/-/-}(100 \mu \mathrm{l}, 100 \mathrm{nM})$ with Attractene $(1.5 \mu \mathrm{l})$ at $25^{\circ} \mathrm{C}$ for $20 \mathrm{~min}$. The transfection mix was added to the cells dropwise. Cells were collected at $72 \mathrm{hrs}$ post transfection, lysed, and extracts $(50 \mu \mathrm{g})$ were loaded onto a $4-20 \%$ SDS-PAGE gel. Western blots were performed using antibodies against p65, p300, IKK- $\beta$, and $\beta$-Actin. Densitometry was performed using ImageJ software (Wayne Rasband, NIH, USA).

\section{Acknowledgments}

Rachel Van Duyne is a predoctoral student in the Microbiology and Immunology Program of the Institute for Biomedical Sciences at the George Washington University. This work is from a dissertation to be

\section{References}

1. Easley R, Van Duyne R, Coley W, Guendel I, Dadgar S, et al. (2010) Chromatin dynamics associated with HIV-1 Tat-activated transcription. Biochim Biophys Acta 1799: 275-285.

2. Gallo RC (2005) History of the discoveries of the first human retroviruses: HTLV-1 and HTLV-2. Oncogene 24: 5926-5930.

3. Poiesz BJ, Ruscetti FW, Gazdar AF, Bunn PA, Minna JD, et al. (1980) Detection and isolation of type $\mathrm{C}$ retrovirus particles from fresh and cultured lymphocytes of a patient with cutaneous T-cell lymphoma. Proc Natl Acad Sci U S A 77: 7415-7419.

4. Poiesz BJ, Ruscetti FW, Mier JW, Woods AM, Gallo RC (1980) T-cell lines established from human T-lymphocytic neoplasias by direct response to T-cell growth factor. Proc Natl Acad Sci U S A 77: 6815-6819.

5. Yin MJ, Christerson LB, Yamamoto Y, Kwak YT, Xu S, et al. (1998) HTLV-I Tax protein binds to MEKK1 to stimulate IkappaB kinase activity and NFkappaB activation. Cell 93: 875-884.

6. Grassmann R, Aboud M, Jeang KT (2005) Molecular mechanisms of cellular transformation by HTLV-1 Tax. Oncogene 24: 5976-5985.

7. Semmes OJ, Jeang KT (1996) Localization of human T-cell leukemia virus type 1 tax to subnuclear compartments that overlap with interchromatin speckles. J Virol 70: 6347-6357.

8. Taylor JM, Nicot C (2008) HTLV-1 and apoptosis: role in cellular transformation and recent advances in therapeutic approaches. Apoptosis 13: 733-747.

9. Nelson P, Kiriakidou M, Sharma A, Maniataki E, Mourelatos Z (2003) The microRNA world: small is mighty. Trends Biochem Sci 28: 534-540.

10. Kim VN, Han J, Siomi MC (2009) Biogenesis of small RNAs in animals. Nat Rev Mol Cell Biol 10: 126-139.

11. Houzet L, Jeang KT (2011) MicroRNAs and human retroviruses. Biochim Biophys Acta 1809: 686-693.

12. Haasnoot J, de Vries W, Geutjes EJ, Prins M, de Haan P, et al. (2007) The Ebola virus VP35 protein is a suppressor of RNA silencing. PLoS Pathog 3: e86.

13. Wang Y, Kato N, Jazag A, Dharel N, Otsuka M, et al. (2006) Hepatitis C virus core protein is a potent inhibitor of RNA silencing-based antiviral response. Gastroenterology 130: 883-892.

14. Bennasser Y, Le SY, Benkirane M, Jeang KT (2005) Evidence that HIV-1 encodes an siRNA and a suppressor of RNA silencing. Immunity 22: 607-619.

15. Abe M, Suzuki H, Nishitsuji H, Shida H, Takaku H (2010) Interaction of human T-cell lymphotropic virus type I Rex protein with Dicer suppresses RNAi silencing. FEBS Lett 584: 4313-4318.

16. Lu S, Gullen BR (2004) Adenovirus VAl noncoding RNA can inhibit small interfering RNA and MicroRNA biogenesis. J Virol 78: 12868-12876.

17. Lecellier CH, Dunoyer P, Arar K, Lehmann-Che J, Eyquem S, et al. (2005) A cellular microRNA mediates antiviral defense in human cells. Science 308: 557 560 .

18. Delgadillo MO, Saenz P, Salvador B, Garcia JA, Simon-Mateo C (2004) Human influenza virus NS1 protein enhances viral pathogenicity and acts as an RNA silencing suppressor in plants. J Gen Virol 85: 993-999.

19. Qian S, Zhong X, Yu L, Ding B, de Haan P, et al. (2009) HIV-1 Tat RNA silencing suppressor activity is conserved across kingdoms and counteracts translational repression of HIV-1. Proc Natl Acad Sci U S A 106: 605-610.

20. Schnettler E, de Vries W, Hemmes H, Haasnoot J, Kormelink R, et al. (2009) The NS3 protein of rice hoja blanca virus complements the RNAi suppressor function of HIV-1 Tat. EMBO Rep 10: 258-263.

21. de Vries W, Haasnoot J, Fouchier R, de Haan P, Berkhout B (2009) Differential RNA silencing suppression activity of NS1 proteins from different influenza A virus strains. J Gen Virol 90: 1916-1922.

22. Bennasser Y, Yeung ML, Jeang KT (2006) HIV-1 TAR RNA subverts RNA interference in transfected cells through sequestration of TAR RNA-binding protein, TRBP. J Biol Chem 281: 27674-27678.

23. Fabozzi G, Nabel CS, Dolan MA, Sullivan NJ (2011) Ebolavirus proteins suppress the effects of small interfering RNA by direct interaction with the mammalian RNA interference pathway. J Virol 85: 2512-2523. presented to the above program in partial fulfillment of the requirements for the Ph.D. degree. We would like to thank Dr. KT Jeang at NIH for the RISC inhibitor Acriflavine (ACF) as well as the reagents and resources provided from Dr. Zachary Klase. Dr. Klase is a postdoc under supervision of Dr. Jeang. We would also like to thank Dr. Lee Ratner for the use of the pACH clone. We would also like to thank Dr. Pooja Jain for the use of the HTLV-1 infected primary CD4+ T-cells.

\section{Author Contributions}

Conceived and designed the experiments: RVD IG ZK WC AN KKH FK AP. Performed the experiments: RVD IG ZK WC EJ JR. Analyzed the data: RVD IG ZK WC AN KKH FK. Contributed reagents/materials/ analysis tools: RM AN KKH FK ZK. Wrote the paper: RVD FK.

24. Karjee S, Minhas A, Sood V, Ponia SS, Banerjea AC, et al. (2010) The 7a accessory protein of severe acute respiratory syndrome coronavirus acts as an RNA silencing suppressor. J Virol 84: 10395-10401.

25. Ji J, Glaser A, Wernli M, Berke JM, Moradpour D, et al. (2008) Suppression of short interfering RNA-mediated gene silencing by the structural proteins of hepatitis C virus. J Gen Virol 89: 2761-2766.

26. Soldan SS, Plassmeyer ML, Matukonis MK, Gonzalez-Scarano F (2005) La Crosse virus nonstructural protein NSs counteracts the effects of short interfering RNA. J Virol 79: 234-244.

27. Li WX, Li H, Lu R, Li F, Dus M, et al. (2004) Interferon antagonist proteins of influenza and vaccinia viruses are suppressors of RNA silencing. Proc Natl Acad Sci U S A 101: 1350-1355.

28. Haller K, Wu Y, Derow E, Schmitt I, Jeang KT, et al. (2002) Physical interaction of human T-cell leukemia virus type 1 Tax with cyclin-dependent kinase 4 stimulates the phosphorylation of retinoblastoma protein. Mol Cell Biol 22: $3327-3338$.

29. Jin DY, Spencer F, Jeang KT (1998) Human T cell leukemia virus type 1 oncoprotein Tax targets the human mitotic checkpoint protein MAD1. Cell 93: 81-91.

30. Suzuki T, Hirai H, Yoshida M (1994) Tax protein of HTLV-1 interacts with the Rel homology domain of NF-kappa B p65 and c-Rel proteins bound to the NFkappa B binding site and activates transcription. Oncogene 9: 3099-3105.

31. Caron C, Rousset R, Beraud C, Moncollin V, Egly JM, et al. (1993) Functional and biochemical interaction of the HTLV-I Taxl transactivator with TBP. EMBO J 12: 4269-4278.

32. Clemens KE, Piras G, Radonovich MF, Choi KS, Duvall JF, et al. (1996) Interaction of the human T-cell lymphotropic virus type 1 tax transactivator with transcription factor IIA. Mol Cell Biol 16: 4656-4664.

33. Colgin MA, Nyborg JK (1998) The human T-cell leukemia virus type 1 oncoprotein Tax inhibits the transcriptional activity of c-Myb through competition for the CREB binding protein. J Virol 72: 9396-9399.

34. Gachon F, Thebault S, Peleraux A, Devaux C, Mesnard JM (2000) Molecular interactions involved in the transactivation of the human T-cell leukemia virus type 1 promoter mediated by Tax and CREB-2 (ATF-4). Mol Cell Biol 20: 3470-3481.

35. Harrod R, Tang Y, Nicot C, Lu HS, Vassilev A, et al. (1998) An exposed KIDlike domain in human T-cell lymphotropic virus type 1 Tax is responsible for the recruitment of coactivators CBP/p300. Mol Cell Biol 18: 5052-5061.

36. Kashanchi F, Brady JN (2005) Transcriptional and post-transcriptional gene regulation of HTLV-1. Oncogene 24: 5938-5951.

37. Kashanchi F, Duvall JF, Kwok RP, Lundblad JR, Goodman RH, et al. (1998) The coactivator CBP stimulates human T-cell lymphotrophic virus type I Tax transactivation in vitro. J Biol Chem 273: 34646-34652.

38. Nicot C, Mahieux R, Opavsky R, Cereseto A, Wolff L, et al. (2000) HTLV-I Tax transrepresses the human c-Myb promoter independently of its interaction with CBP or p300. Oncogene 19: 2155-2164.

39. Xiao G, Cvijic ME, Fong A, Harhaj EW, Uhlik MT, et al. (2001) Retroviral oncoprotein Tax induces processing of NF-kappaB2/p100 in T cells: evidence for the involvement of IKKalpha. EMBO J 20: 6805-6815.

40. Yin MJ, Paulssen EJ, Seeler JS, Gaynor RB (1995) Protein domains involved in both in vivo and in vitro interactions between human T-cell leukemia virus type I tax and CREB. J Virol 69: 3420-3432.

41. Yamaoka S, Courtois G, Bessia C, Whiteside ST, Weil R, et al. (1998) Complementation cloning of NEMO, a component of the IkappaB kinase complex essential for NF-kappaB activation. Cell 93: 1231-1240.

42. Suzuki T, Kitao S, Matsushime H, Yoshida M (1996) HTLV-1 Tax protein interacts with cyclin-dependent kinase inhibitor p16INK4A and counteracts its inhibitory activity towards CDK4. EMBO J 15: 1607-1614

43. Jeong SJ, Radonovich M, Brady JN, Pise-Masison CA (2004) HTLV-I Tax induces a novel interaction between p65/RelA and p53 that results in inhibition of p53 transcriptional activity. Blood 104: 1490-1497.

44. Giebler HA, Loring JE, van Orden K, Colgin MA, Garrus JE, et al. (1997) Anchoring of CREB binding protein to the human T-cell leukemia virus type 1 
promoter: a molecular mechanism of Tax transactivation. Mol Cell Biol 17: 5156-5164.

45. Kwok RP, Laurance ME, Lundblad JR, Goldman PS, Shih H, et al. (1996) Control of cAMP-regulated enhancers by the viral transactivator Tax through CREB and the co-activator CBP. Nature 380: 642-646.

46. Wu K, Bottazzi ME, de la Fuente C, Deng L, Gitlin SD, et al. (2004) Protein profile of tax-associated complexes. J Biol Chem 279: 495-508.

47. Kehn K, Fuente Cde L, Strouss K, Berro R, Jiang H, et al. (2005) The HTLV-I Tax oncoprotein targets the retinoblastoma protein for proteasomal degradation. Oncogene 24: 525-540.

48. Rahman S, Quann K, Pandya D, Singh S, Khan ZK, et al. (2012) HTLV-1 Tax mediated downregulation of miRNAs associated with chromatin remodeling factors in T cells with stably integrated viral promoter. PLoS One 7: e34490.

49. Zheng ZM (2010) Viral oncogenes, noncoding RNAs, and RNA splicing in human tumor viruses. Int J Biol Sci 6: 730-755.

50. Coley W, Van Duyne R, Carpio L, Guendel I, Kehn-Hall K, et al. (2010) Absence of DICER in monocytes and its regulation by HIV-1.J Biol Chem 285: 31930-31943.

51. Robek MD, Ratner L (1999) Immortalization of CD4(+) and CD8(+) T lymphocytes by human T-cell leukemia virus type 1 Tax mutants expressed in a functional molecular clone. J Virol 73: 4856-4865.

52. Lee WR, Yu XF, Syu WJ, Essex M, Lee TH (1992) Mutational analysis of conserved N-linked glycosylation sites of human immunodeficiency virus type 1 gp41. J Virol 66: 1799-1803.

53. Smith MR, Greene WC (1990) Identification of HTLV-I tax trans-activator mutants exhibiting novel transcriptional phenotypes. Genes Dev 4: 1875-1885.

54. Yamaoka S, Inoue H, Sakurai M, Sugiyama T, Hazama M, et al. (1996) Constitutive activation of NF-kappa B is essential for transformation of rat fibroblasts by the human T-cell leukemia virus type I Tax protein. EMBO J 15: 873-887.

55. Goren I, Semmes OJ, Jeang KT, Moelling K (1995) The amino terminus of Tax is required for interaction with the cyclic AMP response element binding protein. J Virol 69: 5806-5811.

56. Harrod R, Kuo YL, Tang Y, Yao Y, Vassilev A, et al. (2000) p300 and p300/ cAMP-responsive element-binding protein associated factor interact with human T-cell lymphotropic virus type-1 Tax in a multi-histone acetyltransferase/ activator-enhancer complex. J Biol Chem 275: 11852-11857.

57. Smith MR, Greene WC (1992) Characterization of a novel nuclear localization signal in the HTLV-I tax transactivator protein. Virology 187: 316-320.

58. Xiao G, Sun SC (2000) Activation of IKKalpha and IKKbeta through their fusion with HTLV-I tax protein. Oncogene 19: 5198-5203.

59. Basbous J, Bazarbachi A, Granier C, Devaux C, Mesnard JM (2003) The central region of human $\mathrm{T}$-cell leukemia virus type 1 Tax protein contains distinct domains involved in subunit dimerization. J Virol 77: 13028-13035.

60. Gatza ML, Marriott SJ (2006) Genotoxic stress and cellular stress alter the subcellular distribution of human T-cell leukemia virus type 1 tax through a CRM1-dependent mechanism. J Virol 80: 6657-6668.

61. Fu DX, Kuo YL, Liu BY, Jeang KT, Giam CZ (2003) Human T-lymphotropic virus type I tax activates I-kappa B kinase by inhibiting I-kappa B kinaseassociated serine/threonine protein phosphatase 2A. J Biol Chem 278: 14871493.

62. Semmes OJ, Jeang KT (1995) Definition of a minimal activation domain in human T-cell leukemia virus type I Tax. J Virol 69: 1827-1833.

63. Alefantis T, Jain P, Ahuja J, Mostoller K, Wigdahl B (2005) HTLV-1 Tax nucleocytoplasmic shuttling, interaction with the secretory pathway, extracellular signaling, and implications for neurologic disease. J Biomed Sci 12: 961-974.

64. Rousset R, Fabre S, Desbois C, Bantignies F, Jalinot P (1998) The C-terminus of the HTLV-1 Tax oncoprotein mediates interaction with the PDZ domain of cellular proteins. Oncogene 16: 643-654.

65. Chiari E, Lamsoul I, Lodewick J, Chopin C, Bex F, et al. (2004) Stable ubiquitination of human T-cell leukemia virus type 1 tax is required for proteasome binding. J Virol 78: 11823-11832.

66. Watashi K, Yeung ML, Starost MF, Hosmane RS, Jeang KT (2010) Identification of small molecules that suppress microRNA function and reverse tumorigenesis. J Biol Chem 285: 24707-24716.

67. Ruggero K, Corradin A, Zanovello P, Amadori A, Bronte V, et al. (2010) Role of microRNAs in HTLV-1 infection and transformation. Mol Aspects Med 31: 367-382.

68. Yoshida K, Seo Y, Yamasaki H, Tanoue K, Murakoshi N, et al. (2007) Effect of triangle ventricular pacing on haemodynamics and dyssynchrony in patients with advanced heart failure: a comparison study with conventional bi-ventricular pacing therapy. Eur Heart J 28: 2610-2619.

69. Jiang H, Lu H, Schiltz RL, Pise-Masison CA, Ogryzko VV, et al. (1999) PCAF interacts with tax and stimulates tax transactivation in a histone acetyltransferase-independent manner. Mol Cell Biol 19: 8136-8145.

70. Lemasson I, Polakowski NJ, Laybourn PJ, Nyborg JK (2004) Transcription regulatory complexes bind the human T-cell leukemia virus $5^{\prime}$ and $3^{\prime}$ long terminal repeats to control gene expression. Mol Cell Biol 24: 6117-6126.
71. Lenzmeier BA, Giebler HA, Nyborg JK (1998) Human T-cell leukemia virus type 1 Tax requires direct access to DNA for recruitment of CREB binding protein to the viral promoter. Mol Cell Biol 18: 721-731.

72. Xia T, O'Hara A, Araujo I, Barreto J, Carvalho E, et al. (2008) EBV microRNAs in primary lymphomas and targeting of CXCL-11 by ebv-mirBHRF1-3. Cancer Res 68: 1436-1442.

73. Barth S, Pfuhl T, Mamiani A, Ehses C, Roemer K, et al. (2008) Epstein-Barr virus-encoded microRNA miR-BART2 down-regulates the viral DNA polymerase BALF5. Nucleic Acids Res 36: 666-675.

74. Choy EY, Siu KL, Kok KH, Lung RW, Tsang CM, et al. (2008) An EpsteinBarr virus-encoded microRNA targets PUMA to promote host cell survival. J Exp Med 205: 2551-2560.

75. Lo AK, To KF, Lo KW, Lung RW, Hui JW, et al. (2007) Modulation of LMP1 protein expression by EBV-encoded microRNAs. Proc Natl Acad Sci U S A 104: 16164-16169.

76. Strebel K, Luban J, Jeang KT (2009) Human cellular restriction factors that target HIV-1 replication. BMC Med 7: 48.

77. Bennasser Y, Jeang KT (2006) HIV-1 Tat interaction with Dicer: requirement for RNA. Retrovirology 3: 95.

78. Bennasser Y, Le SY, Yeung ML, Jeang KT (2006) MicroRNAs in human immunodeficiency virus-1 infection. Methods Mol Biol 342: 241-253.

79. Bennasser Y, Yeung ML, Benkirane M, Jeang KT (2006) RNA interference and HIV-1: hits and misses. Curr Opin HIV AIDS 1: 208-211.

80. Haasnoot J, Westerhout EM, Berkhout B (2007) RNA interference against viruses: strike and counterstrike. Nat Biotechnol 25: 1435-1443.

81. Ballaun C, Farrington GK, Dobrovnik M, Rusche J, Hauber J, et al. (1991) Functional analysis of human T-cell leukemia virus type I rex-response element: direct RNA binding of Rex protein correlates with in vivo activity. J Virol 65: 4408-4413.

82. Kusuhara K, Anderson M, Pettiford SM, Green PL (1999) Human T-cell leukemia virus type 2 Rex protein increases stability and promotes nuclear to cytoplasmic transport of gag/pol and env RNAs. J Virol 73: 8112-8119.

83. Narayan M, Kusuhara K, Green PL (2001) Phosphorylation of two serine residues regulates human T-cell leukemia virus type 2 Rex function. J Virol 75: 8440-8448.

84. Satou Y, Nosaka K, Koya Y, Yasunaga JI, Toyokuni S, et al. (2004) Proteasome inhibitor, bortezomib, potently inhibits the growth of adult T-cell leukemia cells both in vivo and in vitro. Leukemia 18: 1357-1363.

85. Mitra-Kaushik S, Harding JC, Hess JL, Ratner L (2004) Effects of the proteasome inhibitor PS-341 on tumor growth in HTLV-1 Tax transgenic mice and Tax tumor transplants. Blood 104: 802-809.

86. Abou-Merhi R, Khoriaty R, Arnoult D, El Hajj H, Dbouk H, et al. (2007) PS341 or a combination of arsenic trioxide and interferon-alpha inhibit growth and induce caspase-dependent apoptosis in KSHV/HHV-8-infected primary effusion lymphoma cells. Leukemia 21: 1792-1801.

87. Nasr R, El-Sabban ME, Karam JA, Dbaibo G, Kfoury Y, et al. (2005) Efficacy and mechanism of action of the proteasome inhibitor PS-341 in T-cell lymphomas and HTLV-I associated adult T-cell leukemia/lymphoma. Oncogene 24: 419-430.

88. Chowdhury IH, Radonovich M, Mahieux R, Pise-Masison C, Muralidhar S, et al. (2003) P53 facilitates degradation of human T-cell leukaemia virus type I Tax-binding protein through a proteasome-dependent pathway. J Gen Virol 84: 897-906.

89. Bellon M, Lepelletier Y, Hermine O, Nicot C (2009) Deregulation of microRNA involved in hematopoiesis and the immune response in HTLV-I adult T-cell leukemia. Blood 113: 4914-4917.

90. Pichler K, Schneider G, Grassmann R (2008) MicroRNA miR-146a and further oncogenesis-related cellular microRNAs are dysregulated in HTLV-1-transformed T lymphocytes. Retrovirology 5: 100.

91. Houzet L, Yeung ML, de Lame V, Desai D, Smith SM, et al. (2008) MicroRNA profile changes in human immunodeficiency virus type 1 (HIV-1) seropositive individuals. Retrovirology 5: 118

92. Yeung ML, Bennasser Y, Watashi K, Le SY, Houzet L, et al. (2009) Pyrosequencing of small non-coding RNAs in HIV-1 infected cells: evidence for the processing of a viral-cellular double-stranded RNA hybrid. Nucleic Acids Res 37: 6575-6586.

93. Chen R, Alvero AB, Silasi DA, Kelly MG, Fest S, et al. (2008) Regulation of IKKbeta by miR-199a affects NF-kappaB activity in ovarian cancer cells. Oncogene 27: 4712-4723.

94. Sakurai K, Furukawa G, Haraguchi T, Inada K, Shiogama K, et al. (2011) MicroRNAs miR-199a-5p and -3p target the Brm subunit of SWI/SNF to generate a double-negative feedback loop in a variety of human cancers. Cancer Res 71: 1680-1689.

95. Lagos D, Pollara G, Henderson S, Gratrix F, Fabani M, et al. (2010) miR-132 regulates antiviral innate immunity through suppression of the p300 transcriptional co-activator. Nat Cell Biol 12: 513-519.

96. O'Hara SP, Splinter PL, Gajdos GB, Trussoni CE, Fernandez-Zapico ME, et al. (2010) NFkappaB p50-CGAAT/enhancer-binding protein beta (C/EBPbeta)mediated transcriptional repression of microRNA let-7i following microbial infection. J Biol Chem 285: 216-225. 